Boston University School of Law Scholarly Commons at Boston University School of Law

Faculty Scholarship

$4-2018$

\title{
Can a Court Change the Law by Saying Nothing?
}

Paul Gugliuzza

Boston University School of Law

Mark A. Lemley

Stanford Law School

Follow this and additional works at: https://scholarship.law.bu.edu/faculty_scholarship

Part of the Courts Commons, and the Intellectual Property Law Commons

\section{Recommended Citation}

Paul Gugliuzza \& Mark A. Lemley, Can a Court Change the Law by Saying Nothing?, 71 Vanderbilt Law Review 765 (2018).

Available at: https://scholarship.law.bu.edu/faculty_scholarship/208

This Article is brought to you for free and open access by Scholarly Commons at Boston University School of Law. It has been accepted for inclusion in Faculty Scholarship by an authorized administrator of Scholarly Commons at Boston University School of Law. For more information, please contact lawlessa@bu.edu. 


\title{
Can a Court Change the Law by Saying Nothing?
}

\author{
Paul R. Gugliuzza* \\ Mark A. Lemley**
}

Can an appellate court alter substantive law without writing an opinion? We attempt to answer that question by conducting a novel empirical investigation into how the Federal Circuit has implemented the Supreme Court's 2014 ruling in Alice v. CLS Bank, the most recent in a series of Supreme Court decisions strengthening patent law's patentable subject matter requirement. Our dataset includes each one of the Federal Circuit's more than 100 decisions on patentable subject matter in the three years since Alice, including affirmances issued without an opinion under Federal Circuit Rule 36.

Including those no-opinion affirmances, the Federal Circuit has found the patent to be invalid in more than $90 \%$ of its decisions. The court's precedential opinions, however, tell a different story: nearly a quarter of them favor the patentee by rejecting challenges to patent validity. This difference is due largely to one remarkable fact: although the court has issued over fifty Rule 36 affirmances finding the asserted patent to be invalid, it has not issued a single Rule 36 affirmance when finding in favor of a patentee. Rather, it has written an opinion in every one of those cases.

As a result, the Federal Circuit's precedential opinions provide an inaccurate picture of how disputes over patentable subject matter are actually resolved. Precedential opinions suggest that any given patent has a decent chance of surviving an eligibility challenge at the Federal

\footnotetext{
* Associate Professor, Boston University School of Law.

** William H. Neukom Professor, Stanford Law School; partner, Durie Tangri LLP. For comments and helpful discussions, thanks to Margo Bagley, Jeremy Bock, Dennis Crouch, Stacey Dogan, Rochelle Dreyfuss, Wendy Gordon, Rose Hagan, Peter Harter, Tim Holbrook, Keith Hylton, Dmitry Karshtedt, Megan La Belle, Jonathan Masur, Mike Meurer, Lisa Ouellette, Kevin Outterson, Arti Rai, Jason Rantanen, Rachel Rebouché, Greg Reilly, Michael Risch, Jay Thomas, Saurabh Vishnubhakat, Melissa Wasserman, and workshop participants at the IP Scholars Conference and the Southeastern Association of Law Schools Annual Conference. Additional thanks to Jason Rantanen and Michael Kwun, whose databases of Federal Circuit decisions were invaluable in preparing this Article, and to James Yoon for research assistance.
}

(C) 2018 Paul R. Gugliuzza \& Mark A. Lemley. 
Circuit. But, in reality, very few patents do. Our findings suggest that, by saying nothing, a court can indeed affect substantive law, or at least the perception of it. This has interesting implications both for the ongoing debate over the legality of Rule 36 and, more broadly, for understanding the differences between the law on the books and the actual experience of litigants.

INTRODUCTION 766

I. The Resurrection of the Patentable SubJect Matter REQUIREMENT .... 769

A. Patentable Subject Matter and the Supreme Court 769

B. $\quad$ Alice in the Federal Circuit: The Doctrine .............. 774

C. $\quad$ The Controversy over Patentable Subject Matter .... 776

II. The Silent JURISPRUdence of PATENTABLE SUBJECT

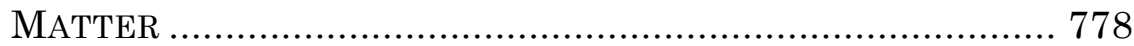

A. Federal Circuit Decisions Generally..................... 778

B. $\quad$ Alice in the Federal Circuit: The Empirics ............. 782

III. Does Rule 36 SkeW SubSTANTIVE LAW? .......................... 791

A. Is Alice an Even Bigger Deal than We Thought? .... 791

B. Is the Federal Circuit Changing the Law Through the Way It Decides Cases?........................................ 796

C. $\quad$ The Proper Role of Rule 36 ................................ 804

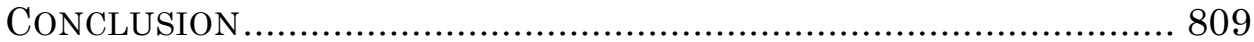

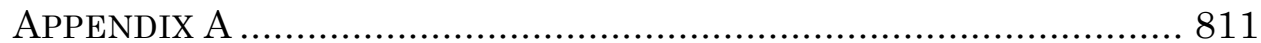

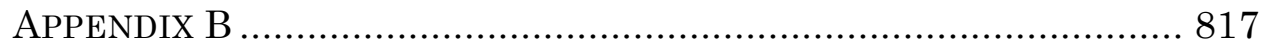

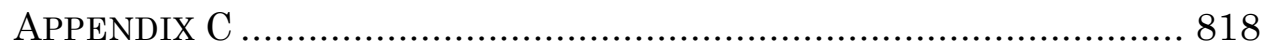

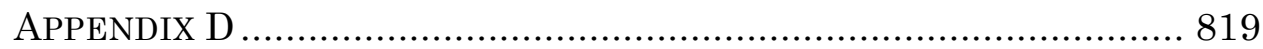

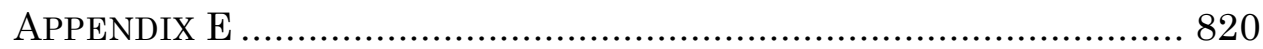

\section{INTRODUCTION}

The Supreme Court's patentable subject matter decisions between 2010 and 2014 upended the law in important ways. In four decisions culminating in Alice Corp. v. CLS Bank International, ${ }^{1}$ the Court reinvigorated the long-dormant doctrine, setting forth a new test for assessing patentable subject matter that threw out prior Federal Circuit precedent and sent the patent bar into a tizzy.

1. 134 S. Ct. 2347 (2014). 
In this Article, we conduct a novel empirical investigation into how the Federal Circuit has implemented Alice in the three years since it was decided. Our dataset includes each of the Federal Circuit's 104 post-Alice decisions on patentable subject matter, including precedential opinions, nonprecedential opinions, and, crucially, affirmances without opinion under Federal Circuit Rule $36 .{ }^{2}$

Among our more interesting findings is that the Federal Circuit writes precedential opinions much more frequently when it rules in favor of the patentee than when it invalidates the patent. Overall, the Federal Circuit has found the patent to be valid in only $7.7 \%$ of its postAlice decisions on patentable subject matter. But nearly three times as many $(21.2 \%)$ of the court's post-Alice precedential opinions favor the patentee by rejecting challenges to patent validity. Remarkably, although the court has issued over fifty Rule 36 affirmances finding the asserted patent to be invalid, it has not issued a single Rule 36 affirmance when finding in favor of a patentee. Rather, it has written an opinion in every one of those cases.

The disproportionate number of precedential opinions favoring patentees obscures the actual trends in the cases. It also has significant implications for substantive patent law and for the process of appellate judging. For example, one might interpret the Federal Circuit's preference for precedential opinions when ruling in favor of patentees as evidence of the court undermining the Supreme Court's restrictions on patentable subject matter, which would be consistent with longstanding perceptions of the Federal Circuit as biased in favor of patent owners. $^{3}$ Similarly, the large number of Rule 36 affirmances invalidating patents could indicate that the court is "hiding" those decisions, lending support to recent arguments that the Federal

2. Including Rule 36 affirmances is essential to providing an accurate empirical analysis of the Federal Circuit's decisionmaking practices. See, e.g., Kimberly A. Moore, Markman Eight Years Later: Is Claim Construction More Predictable?, 9 LEWIS \& ClARK L. REV. 231, 234 (2005); David L. Schwartz, Practice Makes Perfect? An Empirical Study of Claim Construction Reversal Rates in Patent Cases, 107 Mich. L. REv. 223, 235 (2008); see also John R. Allison et al., Understanding the Realities of Modern Patent Litigation, 92 TEX. L. REV. 1769, 1771 (2014) (noting that many empirical studies of patent litigation omit unreported decisions such as Rule 36 affirmances). Because Rule 36 affirmances say nothing besides "AFFIRMED," however, one must review the docket and the parties' briefs for each case to determine the legal issues in dispute, which we have done for this Article. Appendix A, infra, provides a full list of the decisions included in our dataset. For administrability, we ended our data collection on June 19, 2017, the three-year anniversary of Alice. For a more detailed description of our methodology, see infra notes 80, 84 .

3. See generally Craig Allen Nard \& John F. Duffy, Rethinking Patent Law's Uniformity Principle, 101 Nw. U. L. REV. 1619, 1628 n.40 (2007) (summarizing conflicting arguments about whether the Federal Circuit has, in fact, been "pro-patent"). 
Circuit's use of Rule 36 is unwise as a policy matter, inconsistent with the requirements of the Patent Act, or even unconstitutional. 4

We think, however, that there are two other more likely explanations for the disproportionate number of precedential opinions upholding validity against challenges to patentable subject matter. The first relates to the fact that, as high as the invalidity rate is in the Federal Circuit (92.3\%), the invalidity rate in the district court and Patent Office proceedings that have so far been reviewed by the Federal Circuit is even higher: $96.2 \%$. Thus, the Federal Circuit has had very few opportunities to even consider affirming a ruling of validity via Rule 36. And appeals from rulings of invalidity are now such a common occurrence in the Federal Circuit that many of those cases may be the types of "easy" cases for which Rule 36 was designed. But there are many more district court decisions upholding validity than have been appealed to the Federal Circuit so far. ${ }^{5}$ Once the Federal Circuit begins reviewing more decisions upholding validity, the court's high rate of finding invalidity could decrease.

A second reason for the disproportionate number of precedential opinions upholding validity is that the judges of the Federal Circuit are simply responding to the demands of their audience, as one might expect from a semi-specialized court. ${ }^{6}$ After four Supreme Court decisions in four years ruling against the patentee on patentable subject matter, ${ }^{7}$ and another six months of post-Alice Federal Circuit decisions

4. See, e.g., Dennis Crouch, Wrongly Affirmed Without Opinion, 52 WAKE Forest L. REV. 561, 562-63 (2017); Gene Quinn \& Peter Harter, Does the Federal Circuit's Use of Rule 36 Call into Question Integrity of the Judicial Process?, IPWATCHDOG (Feb. 14, 2017), http://www.ipwatchdog.com/2017/02/14/federal-circuit-rule-36-integrity-judicial-process/id=78261 [https://perma.cc/FEU6-7FCM]; see also Petition for a Writ of Certiorari at 24-29, Leak Surveys, Inc. v. FLIR Sys., Inc., No. 17-194 (U.S. Aug. 1, 2017) (arguing that the Federal Circuit's use of Rule 36 is unlawful in appeals from the Patent Office), cert. denied, 138 S. Ct. 325 (2017) (mem.); Petition for a Writ of Certiorari at 17-20, Celgard, LLC v. Matal, No. 16-1526 (U.S. filed June 19, 2017) (same); Petition for a Writ of Certiorari at 6-7, Petter Invs. v. Hydro Eng'g, No. 17-1055 (U.S. filed Jan. 18, 2018) (arguing that Rule 36 affirmances in appeals from district court litigation violate the Fifth Amendment's Due Process Clause), cert. denied, 2018 WL 575049 (U.S. Apr. 2, 2018) (mem.). But see Matthew J. Dowd, An Examination of the Federal Circuit's Use of Rule 36 Affirmances (Feb. 25, 2017) (unpublished manuscript), https://ssrn.com/abstract=2920306 [https://perma.cc/LU8H-BARN] (defending the Federal Circuit's use of Rule 36). For an explanation of the argument that Rule 36 violates the Patent Act, see infra Section III.B.

5. See infra Section III.A.

6. See Lawrence Baum, Judges and Their Audiences: A Perspective on Judicial BEHAVIOR 99 (2006).

7. Alice Corp. v. CLS Bank Int'l, 134 S. Ct. 2347 (2014); Ass'n for Molecular Pathology v. Myriad Genetics, Inc., 569 U.S. 576 (2013); Mayo Collaborative Servs. v. Prometheus Labs., Inc., 566 U.S. 66 (2012); Bilski v. Kappos, 561 U.S. 593 (2010). 
invalidating patents, ${ }^{8}$ patent applicants, litigants, district judges, and the Patent Office needed examples of inventions that remained patent eligible. The Federal Circuit has delivered by writing a precedential opinion nearly every time it has concluded that a patent is valid. But as a consequence, the court's precedential opinions provide an inaccurate picture of how disputes over patentable subject matter are actually resolved.

In this Article, we take a step toward correcting any misconceptions about the law of patentable subject matter by providing empirical evidence on how the Federal Circuit has dealt with Alice on appeal, including through the often-overlooked mechanism of Rule 36 affirmances without opinion. ${ }^{9}$ In Part I, we discuss the doctrine of patentable subject matter and the controversial changes Alice and its progeny have wrought. In Part II, we present our empirical evaluation of every Federal Circuit decision on patentable subject matter since Alice. Finally, in Part III, we discuss the implications of our findings for both the substantive law of patentable subject matter and the role of Rule 36 in shaping the contours of legal doctrine. Whether in patent law or in other fields, understanding the operation of law in practice requires looking beyond written opinions to see what the courts are saying when they say nothing.

\section{The ResurRection of the Patentable Subject Matter REQUIREMENT}

To provide context for our empirical analysis, we first offer an introduction to the patentable subject matter requirement and the controversy surrounding current doctrine.

\section{A. Patentable Subject Matter and the Supreme Court}

Section 101 of the Patent Act permits patents on any new and useful "process, machine, manufacture, or composition of matter." 10

8. Ultramercial, Inc. v. Hulu, LLC, 772 F.3d 709 (Fed. Cir. 2014); buySAFE, Inc. v. Google, Inc., 765 F.3d 1350 (Fed. Cir. 2014); Planet Bingo, LLC v. VKGS LLC, 576 F. App'x 1005 (Fed. Cir. 2014); Digitech Image Techs., LLC v. Elecs. for Imaging, Inc., 758 F.3d 1344 (Fed. Cir. 2014).

9. As one Federal Circuit judge and a co-author recently noted, "Although Rule 36 affirmances without opinion are not frequently a focus of the academic literature, they account for a significant number of Federal Circuit dispositions.” Evan J. Wallach \& Jonathan J. Darrow, Federal Circuit Review of USPTO Inter Partes Review Decisions, by the Numbers: How the AIA Has Impacted the Caseload of the Federal Circuit, 98 J. PAT. \& TRADEMARK OFF. Soc'y 105, 113 (2016) (internal quotation marks omitted); see also infra Figure 1 (reporting that Rule 36 affirmances account for $42.3 \%$ of Federal Circuit decisions in appeals from district courts and the Patent and Trademark Office).

10. 35 U.S.C. $\S 101(2012)$. 
Despite that broad language, courts have long held that $\S 101$ contains an "implicit exception" that prohibits patenting laws of nature, natural phenomena (sometimes, "product[s] of nature"11), and abstract ideas. ${ }^{12}$ The story of how the courts have developed and applied that exception is long and complicated. ${ }^{13}$ For the purpose of this Article, we can pick up the thread in the 1980s, when the Supreme Court turned away from prior case law limiting the patent eligibility of relatively primitive innovations in biotechnology ${ }^{14}$ and computer software. ${ }^{15}$ Early in that decade, the Court upheld the patent eligibility of a self-replicating, genetically modified bacterium, ${ }^{16}$ and also confirmed the eligibility of a computer-driven process for molding rubber. ${ }^{17}$ Ushering in a new era, the Court selectively quoted from the legislative history of the 1952 Patent Act to claim that "Congress intended statutory subject matter to 'include anything under the sun that is made by man.'" 18

11. Myriad, 569 U.S. at 580.

12. Alice, 134 S. Ct. at 2354.

13. For thorough analyses of the evolution of the patentable subject matter requirement, see, for example, 1 Peter S. Menell ET AL., Intellectual Property in the NeW Technological Age 277-314 (2017); U.S. Patent \& Trademark Office, Patent Eligible Subject Matter: REPORT ON Views AND RECOMMENDATIONS FROM THE PUBLIC 3-16 (2017), https://www.uspto.gov/ sites/default/files/documents/101-Report_FINAL.pdf [https://perma.cc/K3ML-5PRY]; Margo A. Bagley, Patent Barbarians at the Gate: The Who, What, When, Where, Why and How of U.S. Patent Subject Matter Eligibility Disputes, in PATENT LaW IN GLOBAL PersPeCTIVE 149, 151-55 (Ruth L. Okediji \& Margo A. Bagley eds., 2014); Julie E. Cohen \& Mark A. Lemley, Patent Scope and Innovation in the Software Industry, 89 CALIF. L. REV. 1, 8-11 (2001); Kevin Emerson Collins, Propertizing Thought, 60 SMU L. REv. 317, 345-60 (2007); Peter S. Menell, Forty Years of Wondering in the Wilderness and No Closer to the Promised Land: Bilski's Superficial Textualism and the Missed Opportunity to Return Patent Law to Its Technology Mooring, 63 STAN. L. Rev. 1289, 1292-305 (2011); Pamela Samuelson, Benson Revisited: The Case Against Patent Protection for Algorithms and Other Computer Program-Related Inventions, 39 EMORY L.J. 1025, 1032-98 (1990); Joshua D. Sarnoff, Patent-Eligible Inventions After Bilski: History and Theory, 63 HASTINGs L.J. 53, 63-84 (2011); Peter S. Menell \& Jeffrey A. Lefstin, Rethinking Patent Eligibility for the Modern Scientific Age 7-10 (U.C. Berkeley Pub. Law, Research Paper No. 2402776, 2014; U.C. Hastings, Research Paper No. 97, 2014), https://ssrn.com/abstract=2402776 [https://perma.cc/9Q5M-26NJ].

14. Funk Bros. Seed Co. v. Kalo Inoculant Co., 333 U.S. 127, 131 (1948) (invalidating a patent on a composition of two naturally occurring bacteria).

15. Parker v. Flook, 437 U.S. 584, 594 (1978) (holding that a process that used a mathematical formula for updating alarm limits during catalytic conversion was not patent eligible); Gottschalk v. Benson, 409 U.S. 63, 71-72 (1972) (holding ineligible for patenting a computer program that used a mathematical formula to convert binary-coded decimal numerals into pure binary numbers).

16. Diamond v. Chakrabarty, 447 U.S. 303, 310 (1980).

17. Diamond v. Diehr, 450 U.S. 175, 187 (1981).

18. Id. at 182 (quoting S. REP. No. 1979, at 5 (1952); H.R. REP. No. 1923, at 6 (1952)); accord Chakrabarty, 447 U.S. at 309. The full sentence in the committee reports suggests a different understanding: "A person may have 'invented' a machine or a manufacture, which may include anything under the sun that is made by man, but it is not necessarily patentable under section 101 unless the conditions of [this] title are fulfilled.” S. REP. NO. 1979, at 5; H.R. REP. NO. 1923, at 6; see also Bilski v. Kappos, 561 U.S. 593, 641-42 (2010) (Stevens, J., concurring in the judgment) (criticizing the truncated presentation of the legislative history). 
In the wake of those Supreme Court decisions, the Federal Circuit further loosened restrictions on patent eligibility, rendering the patentable subject matter requirement effectively a dead letter. ${ }^{19}$ In the 1990s and early 2000s, the Patent Office regularly issued-and the Federal Circuit regularly upheld the validity of-patents on computer software, ${ }^{20}$ business methods, ${ }^{21}$ and isolated DNA sequences. ${ }^{22}$ After the bursting of the internet stock bubble in 2001, however, many software and business method patents ended up in the hands of patent assertion entities ("PAEs," or, more controversially, "patent trolls"). ${ }^{23}$ Around the same time, concerns began to emerge that DNA patents were creating an anticommons inhibiting the emergence of useful gene therapies. ${ }^{24}$ Also, because patents covering genetic information are nearly impossible to invent around, those patents sometimes appeared to be impairing clinical practice, hindering the development of diagnostics and therapeutics, and, ultimately, harming patients. ${ }^{25}$ These considerations, among others, led to widespread calls for tightening the standards of patentability. ${ }^{26}$

In 2006, the Supreme Court briefly flirted with the patentable subject matter requirement in a case it ultimately dismissed as improvidently granted. ${ }^{27} \mathrm{~A}$ year later (and perhaps following the Supreme Court's signal ${ }^{28}$ ), the Federal Circuit cautiously added some teeth to the patentable subject matter requirement in two decisions issued on the same day. In one decision, the court upheld the Patent

19. Mark A. Lemley et al., Life After Bilski, 63 StAn. L. REv. 1315, 1318 (2011).

20. E.g., In re Alappat, 33 F.3d 1526, 1544-45 (Fed. Cir. 1994) (en banc).

21. E.g., State St. Bank \& Tr. Co. v. Signature Fin. Grp., 149 F.3d 1368, 1375 (Fed. Cir. 1998).

22. See generally Linda J. Demaine \& Aaron Xavier Fellmeth, Reinventing the Double Helix: A Novel and Nonobvious Reconceptualization of the Biotechnology Patent, 55 STAN. L. REV. 303, 358-60 (2002) (discussing the relevant case law and the Patent Office's patent-granting practices).

23. James M. Rice, The Defensive Patent Playbook, 30 BerKeley TeCH. L.J. 725, 737-38 (2015).

24. Dan L. Burk \& Mark A. Lemley, The Patent Crisis and How the Courts Can Solve IT 87-89 (2009).

25. Rochelle C. Dreyfuss \& James P. Evans, From Bilski Back to Benson: Preemption, Inventing Around, and the Case of Genetic Diagnostics, 63 Stan. L. ReV. 1349, 1370 (2011) (discussing problems of preemption and overbreadth in biotechnology patents).

26. See, e.g., U.S. Fed. Trade Comm'n, To Promote Innovation: The Proper Balance of COMPETITION AND PATENT LAW AND POLICY 14-15 (2003), https://www.ftc.gov/sites/default/files/ documents/reports/promote-innovation-proper-balance-competition-and-patent-law-and-policy/ innovationrpt.pdf [https://perma.cc/ZTR8-P57R]; see also Lab. Corp. of Am. Holdings v. Metabolite Labs., Inc., 548 U.S. 124, 138 (2006) (Breyer, J., dissenting from the dismissal of certiorari) (arguing for a more rigorous patentable subject matter requirement, noting an "important ongoing debate" about "whether the patent system, as currently administered and enforced, adequately reflects the "careful balance' that 'the federal patent laws ... embod[y]'" (alterations in original)).

27. Lab. Corp., 548 U.S. at 125.

28. See Timothy R. Holbrook, Essay, The Federal Circuit's Acquiescence(?), 66 AM. U. L. REv. 1061, 1076 (2017). 
Office's rejection of an application claiming electromagnetic signals designed to prevent unauthorized copying of digital content, reasoning that a transitory signal does not fall within the four categories of patentable subject matter listed in $\S 101$ ("process, machine, manufacture, or composition of matter"). ${ }^{29}$ In the other decision, the Federal Circuit held that a method of requiring and conducting arbitration was not patentable subject matter, emphasizing that, although some business methods are patent eligible, the application at issue impermissibly claimed the "mental processes" used to resolve a legal dispute. ${ }^{30}$

The Supreme Court's renewed interest in patentable subject matter began in 2010 with Bilski v. Kappos. ${ }^{31}$ In that case, the Supreme Court invalidated a patent on a method of hedging financial risk, holding that it claimed an "abstract idea" and was therefore not patentable subject matter. ${ }^{32}$

Two years later, the Supreme Court considered another patentable subject matter dispute, Mayo Collaborative Services $v$. Prometheus Laboratories, Inc., which involved diagnostic tests used to help doctors determine whether the dosage of a particular drug was too low or too high. ${ }^{33}$ The patent-in-suit claimed a method of administering the drug to a patient, measuring its metabolite levels in the body, and comparing those levels to ranges disclosed in the patent to determine whether dosage should be increased or decreased. ${ }^{34}$ In holding that the patent did not satisfy the patentable subject matter requirement, the Court first ruled that the correlation between metabolite levels and drug safety and efficacy recited in the patent was a "law of nature," 35 or, perhaps more precisely, a fact about the world. Putting aside that unpatentable correlation, the Court then concluded that the patent contained no other "inventive concept," which the Court held was essential to satisfying the patentable subject matter requirement. ${ }^{36}$ Rather, in telling doctors to administer the drug and determine its

29. In re Nuijten, 500 F.3d 1346, 1357 (Fed. Cir. 2007).

30. In re Comiskey, 499 F.3d 1365, 1376 (Fed. Cir. 2007) (citing Parker v. Flook, 437 U.S. 584 (1978); Gottschalk v. Benson, 409 U.S. 63 (1972)). The Federal Circuit later revised and vacated its original opinion but reached the same result. See In re Comiskey, 554 F.3d 967, 977 (Fed. Cir. 2009).

31. 561 U.S. $593(2010)$.

32. Id. at 609. In the decision below, the en banc Federal Circuit had also invalidated the patent, building on its prior rulings in Nuijten and Comiskey strengthening the patentable subject matter requirement. See In re Bilski, 545 F.3d 943 (Fed. Cir. 2008) (en banc).

33. 566 U.S. 66,72 (2012).

34. Id. at $74-75$.

35. Id. at 77 .

36. Id. at 72-73. 
metabolite levels, the patent simply recited "well-understood, routine, conventional activity" that doctors already engaged in. ${ }^{37}$ In other words, the patent did not comply with the eligibility requirement because it merely instructed doctors to apply established techniques to a newly discovered fact about the world.

After a 2013 decision holding that isolated DNA segments are not patentable subject matter because they are "product[s] of nature," 38 the Court in 2014 decided its most recent patentable subject matter case, Alice ${ }^{39}$ Alice involved patents related to a computer program that used an intermediary to mitigate the risk that only one party to a financial transaction would perform its obligation. ${ }^{40}$ In its opinion invalidating the patents, the Court drew on Mayo to articulate a twostep test that serves as the foundation for eligibility analysis under current law, regardless of whether the basis for challenge is that the patent claims a law of nature, product of nature, natural phenomenon, or abstract idea. According to the Court, the first step is to determine whether the patent claim is directed to one of those "patent-ineligible concepts." 41 If so, the next question is whether there are "additional elements" that "transform" the claim into a patent-eligible application of the underlying concept. ${ }^{42}$ The Court in Alice explained that this second step of the analysis is "a search for an 'inventive concept'-i.e., an element or combination of elements that is 'sufficient to ensure that the patent in practice amounts to significantly more than a patent upon the [ineligible concept] itself." " 43

Applying that test to the facts of the case, the Court first determined that using intermediaries to mitigate risk was an abstract idea, in part because, like risk hedging in Bilski, "intermediated settlement is a fundamental economic practice long prevalent in our system of commerce." ${ }^{44}$ On the second step, the Court concluded that merely performing that abstract idea on a general-purpose computer,

37. Id. at $79-80$.

38. Ass'n for Molecular Pathology v. Myriad Genetics, Inc., 569 U.S. 576, 595 (2013). In the same decision, the Court upheld patents on synthetically created DNA because it does not occur in nature. Id. at 594-95. That is the only time the Supreme Court has found an invention to satisfy the patentable subject matter requirement in its recent string of cases.

39. Alice Corp. v. CLS Bank Int'l, 134 S. Ct. 2347 (2014).

40. Id. at $2351-52$.

41. Id. at 2355 .

42. Id.

43. Id. (quoting Mayo Collaborative Servs. v. Prometheus Labs., Inc., 566 U.S. 66, 72-73 (2012)).

44. Id. at 2356 (internal quotation marks omitted) (quoting Bilski v. Kappos, 561 U.S. 593, 611 (2010)). 
as the patent claimed, did not represent the "inventive concept" required for patent eligibility. ${ }^{45}$

\section{B. Alice in the Federal Circuit: The Doctrine}

Since Alice, the Federal Circuit has issued 104 decisions on patentable subject matter. ${ }^{46}$ As explained in detail below, the vast majority of those decisions find the claimed invention not to be patent eligible. But, in contrast to the Supreme Court's recent case law, the Federal Circuit has upheld a few patents against eligibility challenges, almost invariably in precedential opinions. The Federal Circuit's postAlice patentable subject matter decisions cluster in two technological areas: information technology ("IT") and biotechnology.

IT-related inventions the Federal Circuit has found eligible include a patent addressing the problem of retaining website visitors upon the click of an advertising link, ${ }^{47}$ a patent on a "self-referential table for a computer database," 48 a patent on filtering internet content, ${ }^{49}$ and a patent on a computerized process for synchronizing animation with sound. ${ }^{50}$ Some observers have synthesized the Supreme Court's and the Federal Circuit's case law into a "technological arts" test, concluding that "advances in non-technological disciplines-such as business, law, or the social sciences" are not patent eligible merely because they employ computer technology, as illustrated by Alice and Bilski.51 On the other hand, patents covering technological improvements in computer hardware or software itself are patent

45. Id. at 2357-58 (citing Parker v. Flook, 437 U.S. 584, 594 (1978); Gottschalk v. Benson, 409 U.S. 63, 67 (1972)).

46. For the methodology we used to arrive at this number, see infra note 84 .

47. DDR Holdings, LLC v. Hotels.com, L.P., 773 F.3d 1245, 1257 (Fed. Cir. 2014).

48. Enfish, LLC v. Microsoft Corp., 822 F.3d 1327, 1337 (Fed. Cir. 2016).

49. Bascom Glob. Internet Servs., Inc. v. AT\&T Mobility LLC, 827 F.3d 1341, 1350 (Fed. Cir. 2016).

50. McRO, Inc. v. Bandai Namco Games Am. Inc., 837 F.3d 1299, 1315 (Fed. Cir. 2016).

51. Ultramercial, Inc. v. Hulu, LLC, 772 F.3d 709, 721 (Fed. Cir. 2014) (Mayer, J., concurring) ("A rule holding that claims are impermissibly abstract if they are directed to an entrepreneurial objective, such as methods for increasing revenue, minimizing economic risk, or structuring commercial transactions, rather than a technological one, would comport with the guidance provided in both Alice and Bilski."); Joshua L. Sohn, A Defense of the Current Jurisprudence on Section 101, LAW360 (Oct. 7, 2016), http://www.law360.com/articles/846930/a-defense-of-thecurrent-jurisprudence-on-section-101 [https://perma.cc/VL78-SM22] ("[T]he Federal Circuit has consistently invalidated patent claims that simply apply economic, business, or human-interaction practices on a computer without improving the computer itself or any other technological art."). 
eligible, as illustrated by Federal Circuit decisions upholding eligibility ${ }^{52}$ and as suggested by the Supreme Court in Alice. ${ }^{53}$

Notably, to satisfy the patentable subject matter requirement, the patent must be directed to the specific technological improvements themselves; ${ }^{54}$ broad, functional claiming of the idea of solving a problem in computer technology remains impermissibly abstract. ${ }^{55}$ Thus, several Federal Circuit cases that uphold eligibility do so only after narrowing the claims by reading in limits from the specification or a claim construction ruling-including claim construction rulings made by the Federal Circuit itself on appeal. ${ }^{56}$

In the realm of biotechnology, inventions are more likely to survive eligibility challenges if the patent covers the making of a new thing, as opposed to the isolation or detection of a naturally occurring chemical. In Ariosa Diagnostics, Inc. v. Sequenom, Inc., for example, the

52. See Matt Levy, Software Patents Will Survive: How Section 101 Law is Settling Down, IPWATCHDOG (Nov. 30, 2016), http://www.ipwatchdog.com/2016/11/30/software-patents-willsurvive/id=75101 [https://perma.cc/2F9R-J5LF] (noting that a claim is patent eligible under recent Federal Circuit case law if it is "a technical improvement to a technical problem").

53. Alice Corp. v. CLS Bank Int'l, 134 S. Ct. 2347, 2359 (2014) (noting that the patents in suit "[did] not, for example, purport to improve the functioning of the computer itself").

54. See RecogniCorp, LLC v. Nintendo Co., 855 F.3d 1322, 1326 (Fed. Cir. 2017) ("The inquiry often is whether the claims are directed to 'a specific means or method' for improving technology or whether they are simply directed to an abstract end-result." (quoting McRO, 837 F.3d at 1314)).

55. See, e.g., Enfish, LLC v. Microsoft Corp., 822 F.3d 1327, 1335-36 (Fed. Cir. 2016) ("[T]he first step in the Alice inquiry ... asks whether the focus of the claims is on the specific asserted improvement in computer capabilities ... or, instead, on a process that qualifies as an 'abstract idea' for which computers are invoked merely as a tool."). For a discussion of the problem of functional claiming in software, see Mark A. Lemley, Software Patents and the Return of Functional Claiming, 2013 WIS. L. REV. 905, 919-36.

56. See, e.g., McRO, 837 F.3d at 1311, 1313 (construing claims in the manner suggested by the patentee and drawing on narrowing statements from the specification to uphold eligibility); Amdocs (Isr.) Ltd. v. Openet Telecom, Inc., 841 F.3d 1288, 1303 (Fed. Cir. 2016) ("The collection, filtering, aggregating, and completing steps all depend upon the invention's unique distributed architecture.... An understanding of how this is accomplished is only possible through an examination of the claims in light of the written description."); $i d$. at 1306 ("While the components and functionality necessarily involved in the ... patent... may be generic at first blush, an examination of the claim in light of the written description reveals that many of these components and functionalities are in fact neither generic nor conventional individually or in ordered combination. Instead, they describe a specific, unconventional technological solution, narrowly drawn to withstand preemption concerns, to a technological problem."); cf. Affinity Labs of Tex., LLC v. DIRECTV, LLC, 838 F.3d 1253, 1259 (Fed. Cir. 2016) ("Even if all the details contained in the specification were imported into the ... claims, the result would still not be a concrete implementation of the abstract idea."); Affinity Labs of Tex., LLC v. Amazon.com Inc., 838 F.3d 1266, 1271 (Fed. Cir. 2016) ("Turning to the second step of the Mayo/Alice inquiry, we conclude that there is nothing in the claims or the specification... that constitutes a concrete implementation of the abstract idea in the form of an 'inventive concept.' "). In one recent case, the majority's reliance on the specification to narrow the claims and save them from invalidation prompted a vigorous dissent from Judge Reyna, who asserted that the practice of looking to the specification "contravenes the fundamental [principle] that the section 101 inquiry is about whether the claims are directed to a patent-eligible invention, not whether the specification is so directed." Amdocs, 841 F.3d at 1307 (Reyna, J., dissenting). 
court invalidated a patent on methods of detecting fetal DNA that floats freely in the mother's body. ${ }^{57}$ Though the discovery of fetal DNA in the mother's bloodstream enabled safer and cheaper genetic testing, ${ }^{58}$ fetal DNA appears naturally in the mother's blood and the techniques used to detect and amplify it were well known. ${ }^{59}$ By contrast, in Rapid Litigation Management Ltd. v. CellzDirect, Inc., the Federal Circuit upheld the eligibility of a patent on a method of preserving hepatocytes, a type of liver cell. ${ }^{60}$ Even though the patent turned on the discovery that hepatocytes could survive multiple freeze-thaw cycles-a natural trait of the cells-the patent claimed an actual, physical method of preservation (not merely observation) that was new. ${ }^{61}$ Consequently, according to the court, the patent was directed to more than an ineligible natural phenomenon, and it contained the inventive concept required by Mayo and Alice. ${ }^{62}$

\section{The Controversy over Patentable Subject Matter}

The current state of patentable subject matter doctrine has elicited vociferous complaints from lawyers, scholars, and even some judges. They criticize Supreme Court and Federal Circuit case law as confusing and unpredictable. ${ }^{63}$ They worry that the restriction of patent eligibility threatens innovation, particularly in the fields of biotechnology and medical diagnostics. ${ }^{64}$ And they lament that the patentable subject matter requirement serves no policy objective not already addressed by the portions of the Patent Act specifically requiring the claimed invention to be nonobvious (that is, "inventive")

57. 788 F.3d 1371, 1376-77 (Fed. Cir. 2015).

58. Rachel Rebouché, Testing Sex, 49 U. RICH. L. REV. 519, 527 (2015).

59. Ariosa, 788 F.3d at 1376-77 (analogizing to Mayo); accord Cleveland Clinic Found. v. True Health Diagnostics LLC, 859 F.3d 1352, 1361-62 (Fed. Cir. 2017) (applying similar reasoning to invalidate patents on methods of testing for the presence of an enzyme associated with cardiovascular disease).

60. 827 F.3d 1042, 1045, 1052 (Fed. Cir. 2016).

61. See id. at 1048 ("[T] he claims are simply not directed to the ability of hepatocytes to survive multiple freeze-thaw cycles. Rather, the claims... are directed to a new and useful laboratory technique for preserving hepatocytes." (emphasis added)).

62. Id. at $1050-52$.

63. See, e.g., John M. Golden, Flook Says One Thing, Diehr Says Another: A Need for Housecleaning in the Law of Patentable Subject Matter, 82 GEO. WASH. L. REV. 1765, 1770 (2014); Christopher M. Holman, Patent Eligibility Post-Myriad: A Reinvigorated Judicial Wildcard of Uncertain Effect, 82 GEO. WASH. L. REV. 1796, 1798 (2014); Paul R. Michel, The Supreme Court Saps Patent Certainty, 82 Geo. WASH. L. ReV. 1751, 1754 (2014); David O. Taylor, Confusing Patent Eligibility, 84 TENN. L. REv. 157, 158-59 (2016).

64. See Rebecca S. Eisenberg, Diagnostics Need Not Apply, 21 B.U. J. ScI. \& TECH. L. 256, 286 (2015) (discussing the unclear policy implications of restrictions on patent eligibility in the field of medical diagnostics). 
and adequately disclosed (that is, not too broadly or too abstractly described). ${ }^{65}$ Those concerns have led the major bar associations representing patent lawyers to call for legislation overturning the Supreme Court's patentable subject matter case law. ${ }^{66}$

The substantive criticisms of current doctrine are, to varying degrees, well taken. Aspects of the patentable subject matter inquiry indisputably overlap with other patentability requirements. ${ }^{67}$ Though the Federal Circuit's cases can be synthesized into somewhat coherent rules (as we attempted to do above), one can certainly identify inconsistencies that make it difficult to predict future outcomes. ${ }^{68}$ And cases such as Ariosa illustrate the risk that the eligibility requirement may exclude some socially valuable inventions from patentability. ${ }^{69}$ That said, the patentable subject matter requirement does serve an important procedural function by providing a mechanism to quickly and cheaply knock out patents that are plainly invalid. ${ }^{70}$ Most key

65. J. Jonas Anderson, Applying Patent-Eligible Subject Matter Restrictions, 17 VAND. J. ENT. \& TECH. L. 267, 281 (2015) (summarizing commentary); see also Jeffrey A. Lefstin \& Peter S. Menell, Restoring the Legislative Framework for Patenting Applications of Scientific Discoveries 23 (U.C. Berkeley Pub. Law, Research Paper No. 2767904, 2016), https://ssrn.com/ abstract=2767904 [https://perma.cc/M2TY-8HEG] ("By shoehorning an extra requirement for inventiveness and a concern over undue preemption into $\S 101$, Mayo contradicts Congress's carefully crafted framework and ignores the legislative mandate to weigh inventiveness and preemption concerns under $\S 103$ and $\S 112$, respectively.”).

66. See Josh Landau, AIPLA Signs on to IPO's Misguided Proposal on $\S 101$, PAT. PRoGRESS (May 17, 2017), https://www.patentprogress.org/2017/05/17/aipla-signs-ipos-misguided-proposal [https://perma.cc/68UF-ZEXN].

67. See Timothy R. Holbrook \& Mark D. Janis, Patent-Eligible Processes: An Audience Perspective, 17 VAND. J. ENT. \& TECH. L. 349, 377 (2015) (discussing the problems of "supplant[ing] a traditional novelty and nonobviousness analysis" with the patentable subject matter requirement); Lemley et al., supra note 19, at 1329-32 (considering potential overlaps of-and distinctions between-patentable subject matter analysis and the disclosure doctrines of $\S 112$ ). But cf. Ultramercial, Inc. v. Hulu, LLC, 772 F.3d 709, 722 n.2 (Fed. Cir. 2014) (Mayer, J., concurring) ("Section 101's vital role-a role that sections 103 and 112 are not equipped to take on-is to cure systemic constitutional infirmities by eradicating those patents which stifle technological progress and unjustifiably impede the free flow of ideas and information." (internal quotation marks omitted) (citation omitted)); John M. Golden, Redundancy: When Law Repeats Itself, 94 TEX. L. REV. 629, 701-03 (2016) (defending "the Supreme Court's move to revive subjectmatter eligibility doctrine and to do so in a way that involves doctrinal overlaps," but citing critical commentary).

68. See Paul R. Gugliuzza, Quick Decisions in Patent Cases, 106 GEO. L.J. (forthcoming 2018) (manuscript at 39-40), https://ssrn.com/abstract=2987289 [https://perma.cc/X98A-KD7B]. But cf. Keith N. Hylton, Patent Uncertainty: Toward a Framework with Applications, 96 B.U. L. REV. 1117,1148 (2016) (noting that it is not unusual for common law doctrines, such as patentable subject matter, to be uncertain in application in the initial stages of development).

69. See Gugliuzza, supra note 68, at 39. But cf. Colleen V. Chien \& Arti K. Rai, An Empirical Analysis of Diagnostic Patenting Post-Mayo 3-4 (Jan. 16, 2018) (unpublished manuscript) (on file with authors) (showing no decline in patenting of diagnostic methods or investment in them since the Supreme Court's invigoration of the eligibility requirement).

70. Gugliuzza, supra note 68, at 40; cf. Saurabh Vishnubhakat, The Antitrusting of Patentability, 48 SETON HALL L. REV. 71, 104 (2017) (noting that “[c]ourts' use of subject-matter 
requirements of patentability, such as nonobviousness and enablement, cannot be resolved until summary judgment at the earliest because they turn on disputed questions of fact. ${ }^{71}$ But patentable subject matter is a question of law that can be resolved on the pleadings-before the parties incur the time and expense of discovery. ${ }^{72}$

Our purpose here is not to resolve the vigorous, ongoing debate over the patentable subject matter requirement. Rather, we hope to illuminate that debate by presenting empirical evidence about the Federal Circuit's practices in deciding the issue.

\section{The Silent JuRisprudence of PATEnTABLE SubJeCt MATTER}

This Part presents the core of our empirical analysis, beginning with background statistics on how the Federal Circuit resolves appeals generally, then turning to a detailed examination of the court's postAlice decisions on patentable subject matter.

\section{A. Federal Circuit Decisions Generally}

The Federal Circuit decides an appeal in one of three ways: by writing a precedential opinion, by writing a nonprecedential opinion, or by affirming without an opinion under Federal Circuit Rule 36. Precedential opinions make law-they bind future panels of the court and can be overturned only by the Federal Circuit sitting en banc or by the Supreme Court. ${ }^{73}$ The Federal Circuit issues nonprecedential opinions, by contrast, when it thinks the disposition will not significantly advance the law. ${ }^{74}$ According to the Federal Circuit's

eligibility as a shortcut to other patentability requirements appears to offer significant savings in decision cost," but that "these savings likely come at the expense of higher error costs" because courts decide validity before resolving important preliminary issues, such as claim construction).

71. Gugliuzza, supra note 68 , at 40.

72. Id. Since Alice the Federal Circuit has regularly held patent claims ineligible on motions to dismiss or for judgment on the pleadings. See, e.g., Content Extraction \& Transmission LLC v. Wells Fargo Bank, 776 F.3d 1343, 1349 (Fed. Cir. 2014); buySAFE, Inc. v. Google, Inc., 765 F.3d 1350, 1352, 1355 (Fed. Cir. 2014). But see Aatrix Software, Inc. v. Green Shades Software, Inc., 882 F.3d 1121, 1125 (Fed. Cir. 2018) (holding that factual allegations in the complaint about the patent's inventiveness required the district court to deny a motion to dismiss on eligibility grounds); Berkheimer v. HP Inc., 881 F.3d 1360, 1370 (Fed. Cir. 2018) (holding that a fact dispute about the patent's inventiveness precluded summary judgment).

73. Newell Cos. v. Kenney Mfg. Co., 864 F.2d 757, 765 (Fed. Cir. 1988).

74. See FED. Cir. InTERnal OPERATING PROCEDURE 10.3 to 10.4 (noting that the court will not publish a precedential opinion if it will not "add significantly to existing law" and listing various other criteria for determining whether to publish a precedential opinion). For a more general discussion of how the federal courts of appeals decide when to issue nonprecedential opinions, see Stephen L. Wasby, Unpublished Court of Appeals Decisions: A Hard Look at the Process, 14 S. CAL. INTERDISC. L.J. 67 (2004). For an overview of criticisms of nonprecedential opinions—and a defense of their use—-by a federal court of appeals judge, see Boyce F. Martin, Jr., 
Internal Operating Procedures, nonprecedential opinions are designed mainly "to tell the losing party why its arguments were not persuasive." 75 Lastly, affirmance without opinion is permissible in five circumstances outlined in Federal Circuit Rule 36. ${ }^{76}$ The purpose of the rule is to allow quick disposition of "easy" cases, ${ }^{77}$ such as cases where the basis for affirmance is that the factual record adequately supports the judgment below. ${ }^{78} \mathrm{~A}$ Rule 36 affirmance is issued per curiam by the three-judge panel and consists of one word and one citation: “AFFIRMED. See Fed. Cir. R. 36." 79

As Figure 1 below illustrates, the relative proportion of precedential opinions, nonprecedential opinions, and Rule 36 affirmances issued by the Federal Circuit has changed noticeably over the past few years. ${ }^{80}$ As recently as 2010 , the court decided fewer than

In Defense of Unpublished Opinions, 60 OHIO ST. L.J. 177, 180 (1999). For a foundational critique of the then-recent increase in the federal courts of appeals' use of nonprecedential opinions, see William L. Reynolds \& William M. Richman, The Non-precedential Precedent-Limited Publication and No-Citation Rules in the United States Courts of Appeals, 78 CoLum. L. REV. 1167, 1205 (1978). And for a debate over whether it is constitutional for the federal courts of appeals to decide cases by nonprecedential opinion, compare Anastasoff v. United States, 223 F.3d 898, 899 (8th Cir.), vacated as moot on reh'g en banc, 235 F.3d 1054 (8th Cir. 2000), which held unconstitutional an Eighth Circuit rule stating that unpublished opinions were not precedent, with Hart v. Massanari, 266 F.3d 1155, 1159 (9th Cir. 2001), which upheld a similar rule in the Ninth Circuit against a constitutional challenge.

75. Fed. Cir. Internal Operating Procedure 10.3.

76. Rule 36 provides, in full:

The court may enter a judgment of affirmance without opinion, citing this rule, when it determines that any of the following conditions exist and an opinion would have no precedential value:

(a) the judgment, decision, or order of the trial court appealed from is based on findings that are not clearly erroneous;

(b) the evidence supporting the jury's verdict is sufficient;

(c) the record supports summary judgment, directed verdict, or judgment on the pleadings;

(d) the decision of an administrative agency warrants affirmance under the standard of review in the statute authorizing the petition for review; or

(e) a judgment or decision has been entered without an error of law.

FED. CIR. R. 36.

77. As Chief Judge Markey explained the year the court adopted the rule, it's for cases "where it's not necessary to explain, even to the loser, why he lost." Chief Judge Howard T. Markey, Remarks at the Seventh Annual Judicial Conference of the United States Court of Appeals for the Federal Circuit (May 24, 1989), in 128 F.R.D. 409, 420 (1989).

78. See, e.g., FED. CIR. R. 36(a)-(c).

79. E.g., FO2GO LLC v. Pinterest, Inc., 672 F. App'x 1001 (Fed. Cir. 2017). Full disclosure: one of us (Lemley) argued that case on appeal for the prevailing party. Even fuller disclosure: the other one of us (Gugliuzza) picked the example, partly for that reason.

80. We used Jason Rantanen's database of Federal Circuit decisions to create Figures 1-3, as well as Figure 15. For a detailed description of the methodology used to build that database, see Jason Rantanen, The Landscape of Modern Patent Appeals, 67 AM. U. L. REV. (forthcoming 2018) (manuscript at 10-18), https://ssrn.com/abstract=3140527 [https://perma.cc/GG6T-7NKY]. 
a third of appeals from the district courts and the Patent and Trademark Office ("PTO") via Rule 36 affirmances; nearly half of the court's decisions were rendered in precedential opinions. By 2016, however, those proportions had almost flipped. The court decided over $40 \%$ of its district court and PTO appeals via Rule 36, and fewer than a third of its decisions were precedential opinions.

\section{Figure 1: MODE OF DisPosition OF FEDERAL CiRCUIT APPEALS FROM DISTRICT COURTS AND THE PTO}

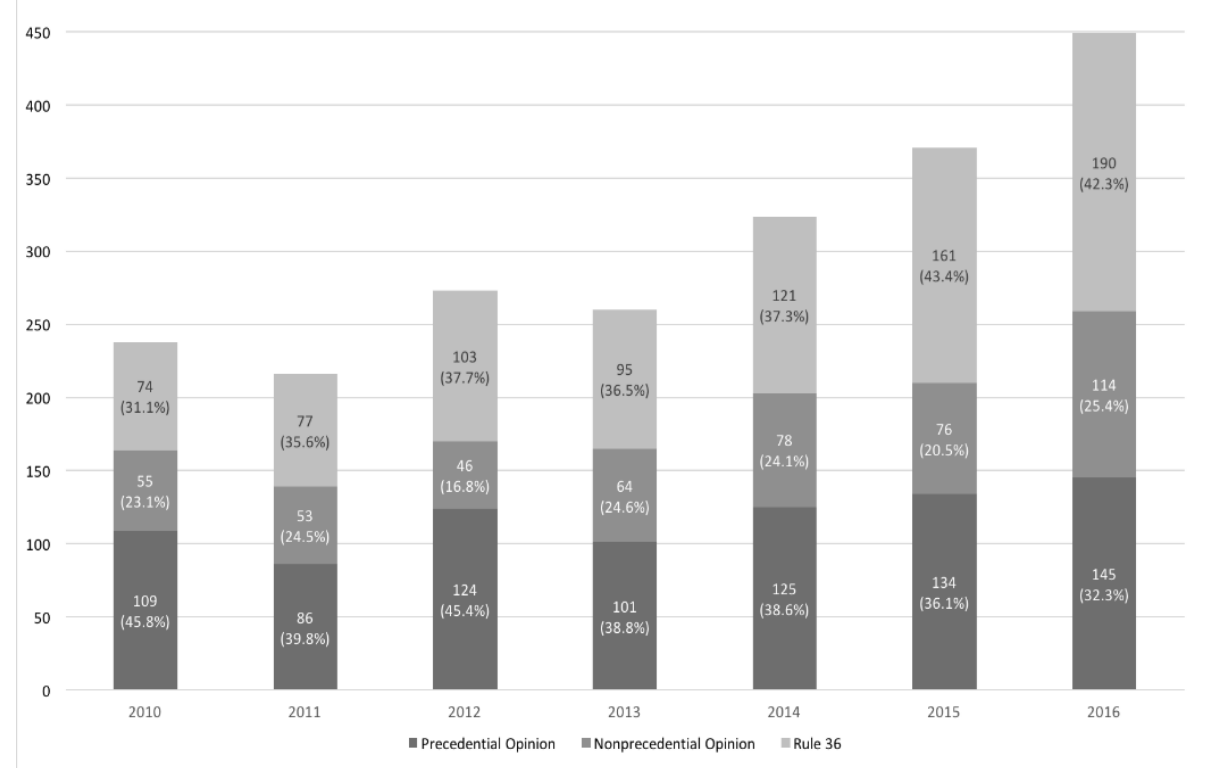

The court's increased use of Rule 36 is usually attributed to the growing number of appeals from the PTO in the wake of the America Invents Act, ${ }^{81}$ which created new opportunities for accused infringers to challenge patent validity in streamlined administrative proceedings beginning in 2012. ${ }^{82}$ Indeed, as Figure 2 below illustrates, the number of Federal Circuit decisions in appeals from the PTO has increased over fourfold, from 46 in 2010 to 202 in 2016, causing an overall increase in the Federal Circuit's PTO and district court docket from 238 decisions in 2010 to 449 decisions in $2016 .{ }^{83}$ Also, the proportion of PTO appeals

81. See, e.g., Holbrook, supra note 28, at 1085-86.

82. For an overview of those proceedings, see Paul R. Gugliuzza, (In)valid Patents, 92 NotRE DAME L. REV. 271, 279-85 (2016).

83. Federal Circuit appeals from the PTO and the district courts consist almost entirely of patent cases. A small fraction of PTO appeals (roughly 5\%) are trademark cases and an even 
resolved through Rule 36 has increased from $37.0 \%$ in 2010 to $50.5 \%$ in 2016.

Figure 2: Mode of Disposition of FEDERAL Circuit APPEALs From THE PTO

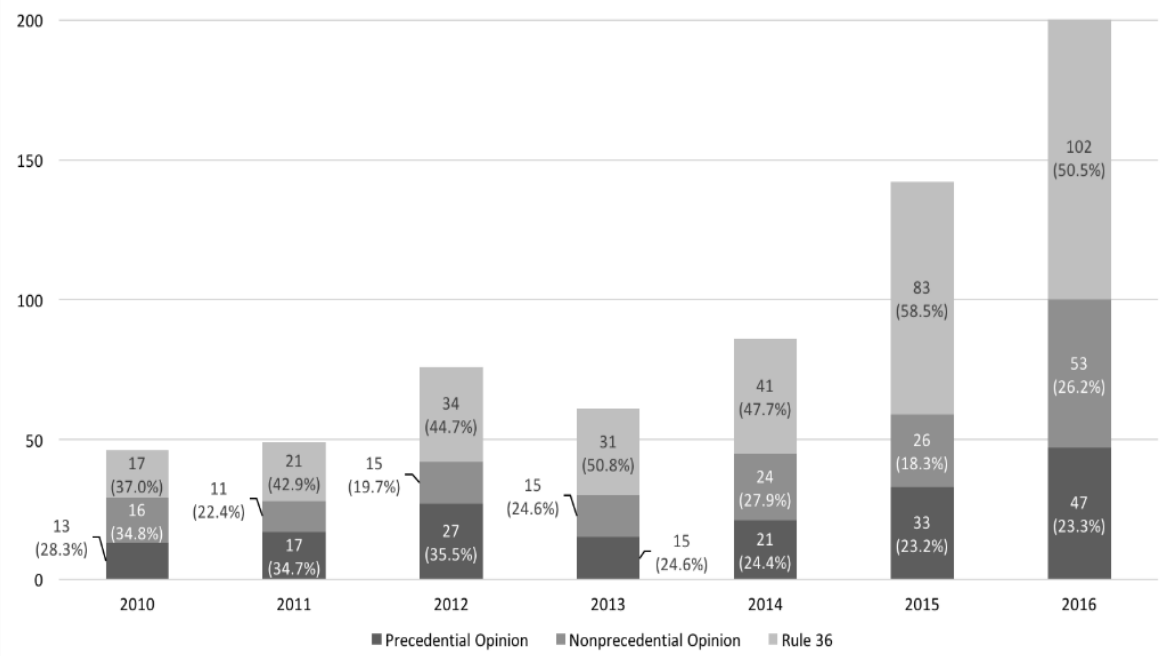

The caseload pressure from the increasing number of PTO appeals appears to be having spillover effects on how the court handles appeals from the district courts. As Figure 3 shows, in appeals from district courts, the percentage of precedential opinions has fallen from $50.0 \%$ in 2010 to $39.7 \%$ in 2016 , and the percentage of Rule 36 affirmances has increased from $29.7 \%$ in 2010 to $35.6 \%$ in 2016.

smaller fraction of district court appeals involve suits against the United States seeking monetary relief. See Appeals Filed, by Category: FY 2016, U.S. CT. APPEALS FOR FED. CIR. (2016), http://www.cafc.uscourts.gov/sites/default/files/the-court/statistics/FY16_Caseload_by

_Category.pdf [https://perma.cc/Z23K-2Z6Y]. Also, patent cases can make it to the Federal Circuit from the International Trade Commission and the Court of Federal Claims, but those numbers are small, too. See id. Thus, the number of district court and PTO appeals provides a close estimate of the Federal Circuit's patent caseload, even if it is over- or underinclusive in minor respects. 


\section{Figure 3: Mode of Disposition of Federal Circuit APPEALs From DISTRICT COURTS}

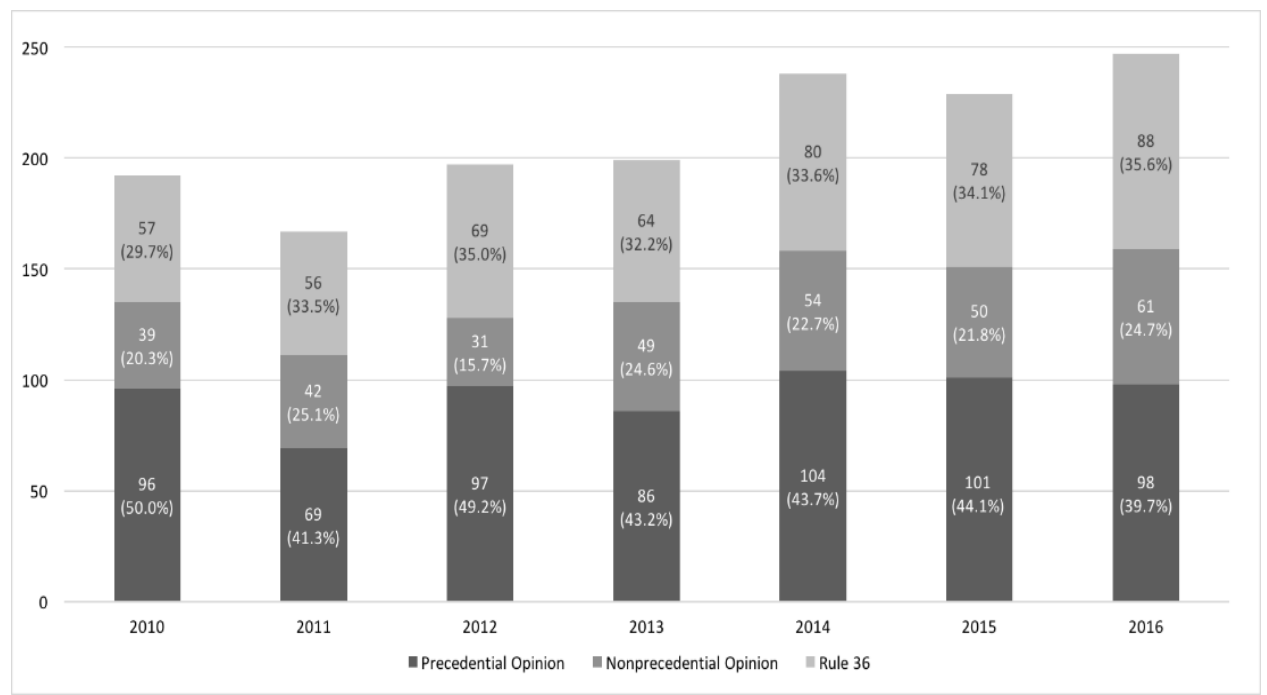

\section{B. Alice in the Federal Circuit: The Empirics}

Turning now to our main subject of interest: How has the Federal Circuit implemented the Alice decision? ${ }^{84}$ The Federal Circuit has issued 33 precedential opinions on patentable subject matter since the Supreme Court decided Alice in June 2014. As Figure 4 shows, 26 of those 33 decisions (78.8\%) found the patent invalid, while seven (21.2\%) found the patent valid. ${ }^{85}$

84. The methodology we used to construct our database of post-Alice Federal Circuit decisions on patentable subject matter was straightforward: Using the Federal Circuit's website, webuilding on the extraordinary work of Michael Kwun, see infra note 153-reviewed every merits decision the Federal Circuit issued over the time period of our study, June 20, 2014, to June 19, 2017. For opinions that decided issues of patentable subject matter, we recorded information including the disposition of the case, the tribunal below, the date, the technological field of the patent or patents being reviewed, the individual judges' votes, and the identity of the opinion author. For Rule 36 affirmances, we reviewed the appellant's brief to see if the appeal involved an issue of patentable subject matter. If it did, we added to our database the same information as we recorded for the opinion cases minus, of course, the identity of the opinion author.

85. We're of course aware of the adage that "[c]ourts do not find patents 'valid,' only that the patent challenger did not carry the 'burden of establishing invalidity in the particular case before the court." Ethicon, Inc. v. Quigg, 849 F.2d 1422, 1429 n.3 (Fed. Cir. 1988) (emphasis omitted) (citation omitted) (quoting Panduit Corp. v. Dennison Mfg. Co., 810 F.2d 1561, 1569 (Fed. Cir. 1987)). We use the word "valid" as shorthand for that lengthier statement of the relevant law. And though one might suggest that, as an appellate court, the Federal Circuit doesn't "find" patents invalid (or valid) - instead it reviews district court and agency decisions making those findingsthe standard of review for patentable subject matter is de novo, OIP Techs., Inc. v. Amazon.com, 
Figure 4: Federal Circuit Precedential Opinions on $§ 101$, PostALICE

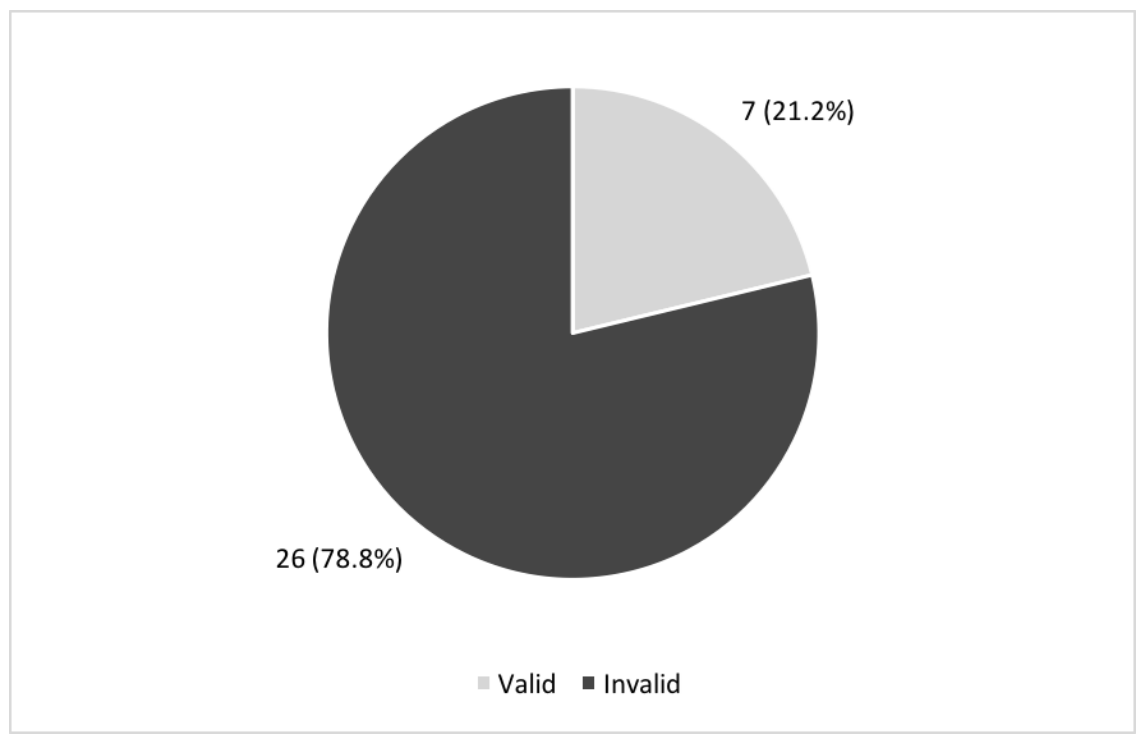

Thus, the post-Alice landscape seems bad for patentees but not catastrophic. Most Federal Circuit decisions invalidate the patent, but certainly not all of them. Indeed, since patentees overall win only $26 \%$ of their cases, ${ }^{86}$ a $21 \%$ win rate on eligibility might not look wildly out of line. ${ }^{87}$

Looking only at precedential opinions, there's more good news for patentees: the Federal Circuit appears to be reining in overzealous invalidations on the ground of patentable subject matter by the district courts and the Patent Trial and Appeal Board ("PTAB"), the tribunal within the PTO that conducts the new proceedings created by the America Invents Act. ${ }^{88}$ Although the Federal Circuit has found the

Inc., 788 F.3d 1359, 1362 (Fed. Cir. 2015), meaning that the distinction seems like one without a difference on this particular issue. That said, we realize that the Federal Circuit may implicitly give deference to the tribunals it oversees despite the formal standard of review, and we discuss that possibility below. See infra Section III.A.

86. See, e.g., Allison et al., supra note 2, at 1787.

87. However, even setting aside the fact that the $21 \%$ win rate on eligibility omits nonprecedential decisions, where patentees are much more likely to lose (as we discuss below), that comparison of the win rate on eligibility to the win rate overall would still be somewhat misleading. To win a patent case the patentee must win on all major issues. See Mark A. Lemley, The Fractioning of Patent Law, in InTELleCtual Property AND THE COMMON LAW 504, 506 (Shyamkrishna Balganesh ed., 2013). Overall invalidity rates are around 43\%, Allison et al., supra note 2 , at 1801 , so a $79 \%$ invalidity rate for patentable subject matter is already notably higher.

88. See 35 U.S.C. §6(a)-(b) (2012). The PTAB also hears appeals from other types of proceedings at the PTO, including appeals from patent applicants who wish to challenge an 
patent invalid in $78.8 \%$ of its post-Alice precedential opinions on patentable subject matter, the district court or the PTAB had found invalidity in whole or in part ${ }^{89}$ in a remarkable $97.0 \%$ (32 of 33) of those cases, as Figure 5 illustrates. ${ }^{90}$ Indeed, six of the seven Federal Circuit precedential opinions finding the patent to be valid reversed a district court decision that had invalidated the patent. ${ }^{91}$

adverse decision by an examiner and from patentees who wish to challenge a decision in an ex parte reexamination. See id.

89. In the figures that follow, we identify cases in which the tribunal below found invalidity in part as "mixed" decisions. The mixed decisions in our dataset are: Apple, Inc. v. Ameranth, Inc., 842 F.3d 1229, 1236 (Fed. Cir. 2016), in which the PTAB found numerous claims of three patents to be ineligible but found some claims of one of those patents to be eligible, and Intellectual Ventures I LLC v. Symantec Corp., 838 F.3d 1307, 1311 (Fed. Cir. 2016), in which the district court found the asserted claims of two patents to be ineligible and the asserted claims of one other patent to be eligible. In both of those cases, the Federal Circuit found all of the relevant claims ineligible. See Ameranth, 842 F.3d at 1245; Intellectual Ventures, 838 F.3d at 1316, 1319, 1322.

90. Four of those 33 cases were appeals from PTAB proceedings. Credit Acceptance Corp. v. Westlake Servs., 859 F.3d 1044 (Fed. Cir. 2017); Ameranth, 842 F.3d at 1235-36; In re Smith, 815 F.3d 816, 817 (Fed. Cir. 2016); Versata Dev. Grp., Inc. v. SAP Am., Inc., 793 F.3d 1306, 1310 (Fed. Cir. 2015). The remaining 29 were appeals from a district court, with the exception of one appeal from the Court of Federal Claims, Thales Visionix Inc. v. United States, 850 F.3d 1343, 1344 (Fed. Cir. 2017). Because that case was a patent infringement suit filed against the U.S. government, for the remainder of this Article, we include it with the district court cases it closely resembles. We also generally combine district court appeals with PTO appeals for the purpose of reporting affirmance rates because the standard of review is the same (de novo, see supra note 85) and because most of the PTAB proceedings (10 of 16) were inter partes (not ex parte) proceedings that resemble district court litigation. Cf. Jason Rantanen, The Federal Circuit's New Obviousness Jurisprudence: An Empirical Study, 16 STAN. TECH. L. REV. 709, 735 (2013) (outlining reasons to be cautious about combining district court and PTO data).

91. The one exception is DDR Holdings, LLC v. Hotels.com, L.P., 773 F.3d 1245, 1259 (Fed. Cir. 2014), in which the Federal Circuit affirmed a district court decision denying the accused infringer's motion for JMOL of invalidity under $§ 101$. Of the Federal Circuit's 24 precedential decisions finding invalidity, 22 affirmed rulings of invalidity by the tribunal below. The other two involved split rulings below. See supra note 89. 
Figure 5: DisPosition BelOW IN CASES THAT RESUlTED IN FEDERAL Circuit PRECEDENTIAL OPINIONS ON $§ 101$, Post- $A L I C E$

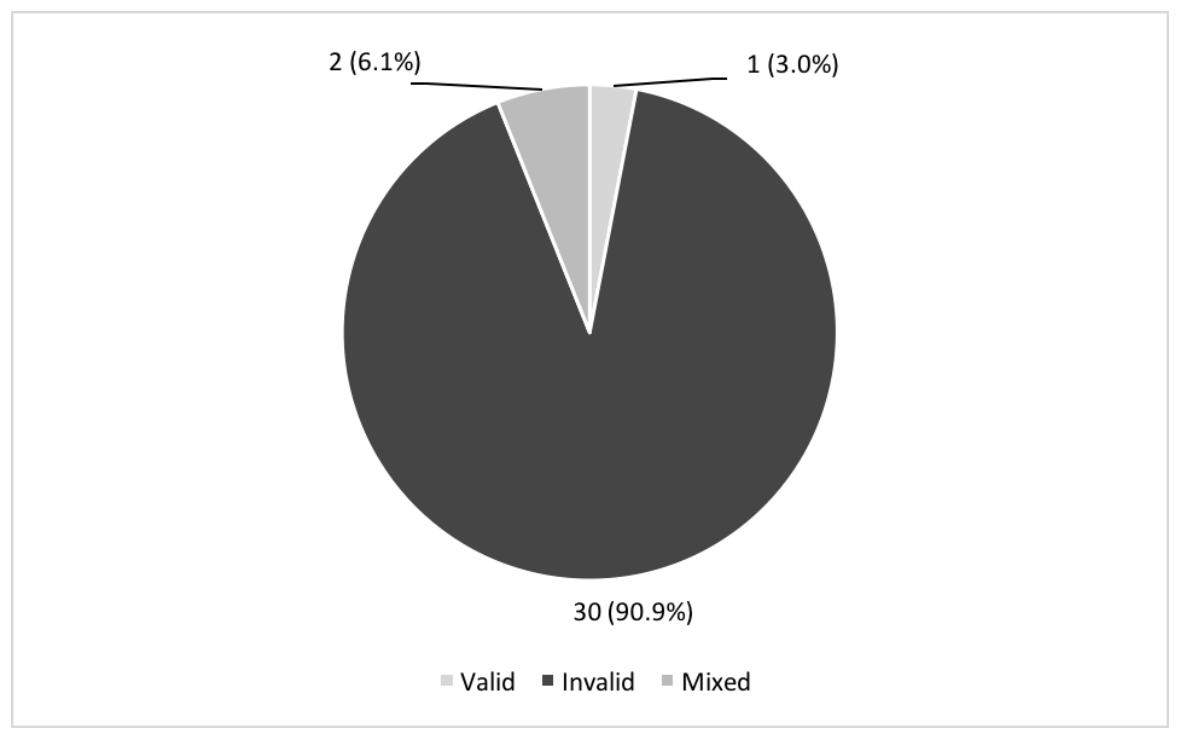

As noted, however, the Federal Circuit decides only a third of its cases by precedential opinion. In our dataset, there are 17 nonprecedential opinions on patentable subject matter. Sixteen of those 17 decisions found the patent to be invalid. Fourteen of those 16 invalidity decisions affirmed district court or PTAB rulings invalidating the patent, while two reversed district court rulings that had upheld the patent. ${ }^{92}$ The one case upholding a patent in a nonprecedential opinion affirmed a district court decision that had found the patent valid. 93

Adding nonprecedential opinions to the mix changes the picture somewhat. The rates at which the Federal Circuit and the tribunals it reviews find invalidity begin to converge, though not entirely. As Figure 6 illustrates, the Federal Circuit found invalidity in 42 of 50 cases $(84.0 \%)$ in which it wrote an opinion, whether precedential or not.

92. Smartflash LLC v. Apple Inc., 680 F. App’x 977, 978 (Fed. Cir. 2017); LendingTree, LLC v. Zillow, Inc., 656 F. App’x 991, 997-98 (Fed. Cir. 2016).

93. Trading Techs. Int'l, Inc. v. CQG, Inc., 675 F. App’x 1001, 1002 (Fed. Cir. 2017). 
Figure 6: Federal CiRCUIT OPINIONS ON $§ 101$, Post- $A L I C E$

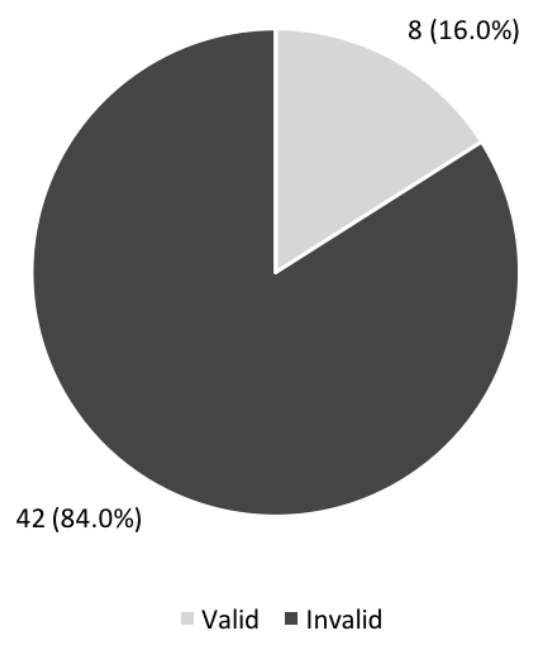

By contrast, as Figure 7 shows, the lower tribunal had originally held the patent invalid in whole or in part in 46 of those 50 cases (92.0\%).

Figure 7: Disposition BeLOW IN CASES THAT RESULTED IN FEDERAL CirCuit OPINIONS ON $§ 101$, Post-ALICE

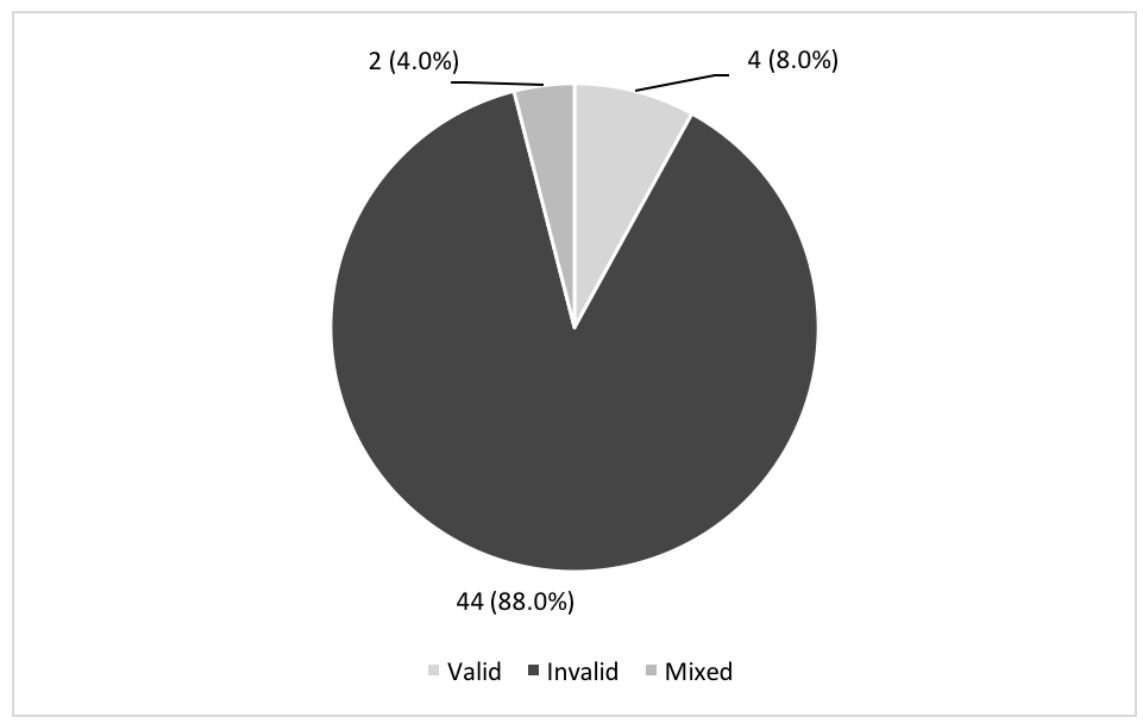


Our picture is still not complete, however, because the majority of Federal Circuit decisions on patentable subject matter since Alice did not involve a written opinion at all. Since Alice, the Federal Circuit has decided 54 patentable subject matter cases under Rule $36 .{ }^{94}$ By definition, all 54 affirmed the tribunal below. Remarkably, every one of the Rule 36 affirmances affirmed a finding of invalidity. Including those cases, the Federal Circuit has allowed patents to survive in only eight of 104 total decisions on patentable subject matter since Alice, an invalidity rate of $92.3 \%$, as Figure 8 illustrates.

Figure 8: Federal Circuit Decisions on $§ 101$, Post-ALICE

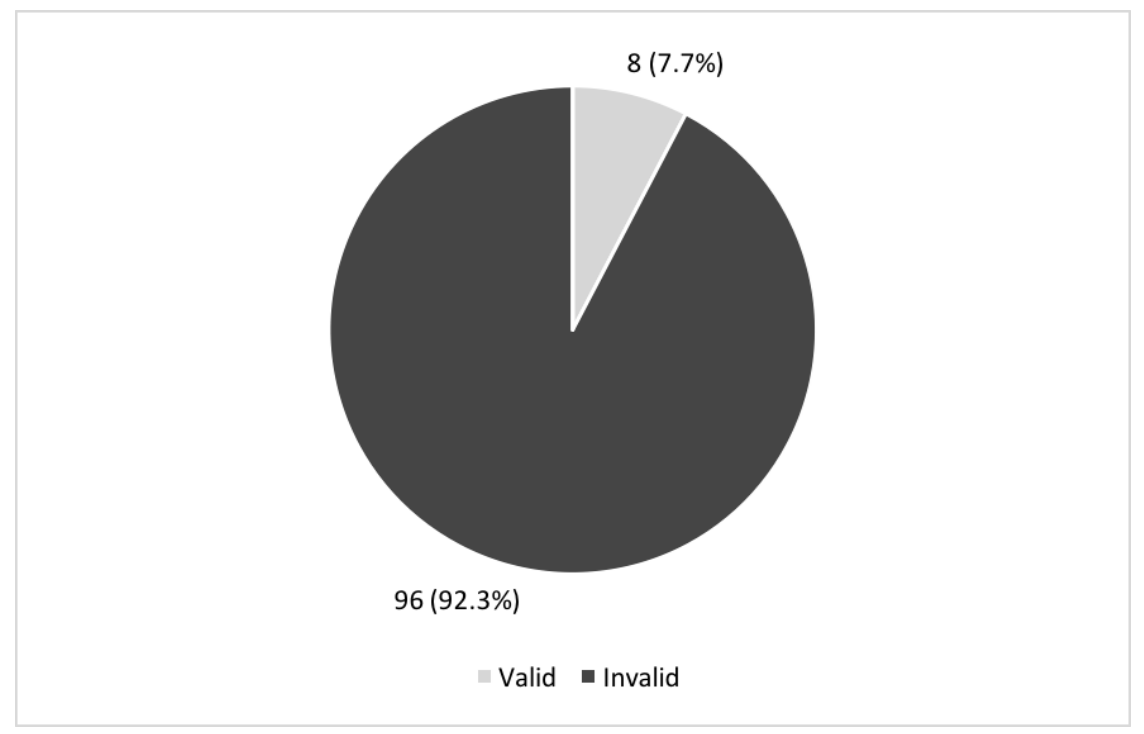

As Figure 9 shows, the population of decisions reviewed by the Federal Circuit had an even higher rate of invalidity-the lower tribunal originally held the patent invalid in whole or in part in 100 of those 104 cases $(96.2 \%)$.

94. For a description of the methodology we used to identify these cases, see supra note 84 . 
Figure 9: Disposition Below in All Federal CiRCuit DeCisions on $\S 101$, PosT-ALICE

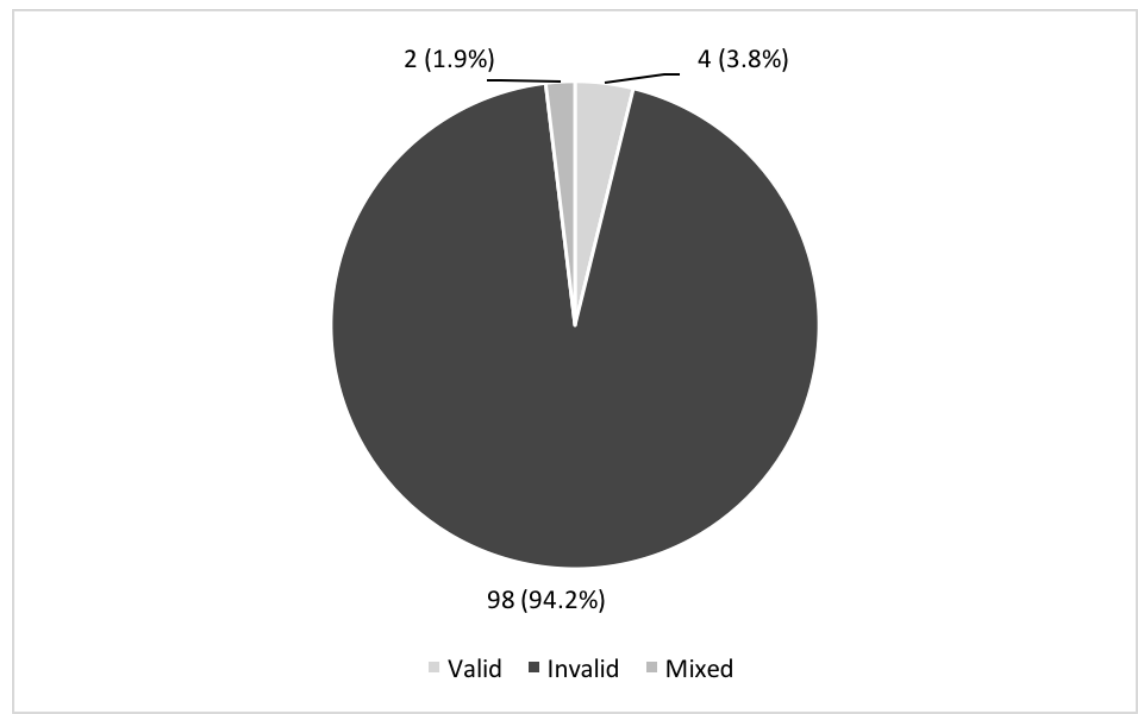

Once Rule 36 decisions are added to the mix, the difference in invalidity rates between the Federal Circuit and the tribunals it reviews largely disappears: $92.3 \%$ for the Federal Circuit, $96.2 \%$ for district courts and the PTAB. In stark contrast to the $21.2 \%$ rate of validity indicated by the Federal Circuit's precedential opinions, patentees are, in fact, overwhelmingly losing in the Federal Circuit on patentable subject matter. And they are overwhelmingly losing in decisions that affirm a finding of invalidity by the tribunal below.

It bears emphasizing that more than two-thirds of the Federal Circuit's patentable subject matter decisions since Alice have generated no precedent, as Figure 10 shows. Though the law memorialized in the court's precedential opinions is on its face not catastrophic for patentees, those opinions represent barely $30 \%$ of the court's total decisions. By contrast, only one of the 71 nonprecedential opinions or Rule 36 affirmances favored the patentee. 
Figure 10: Mode of Disposition of All Federal Circuit $§ 101$ APPEALS, POST-ALICE

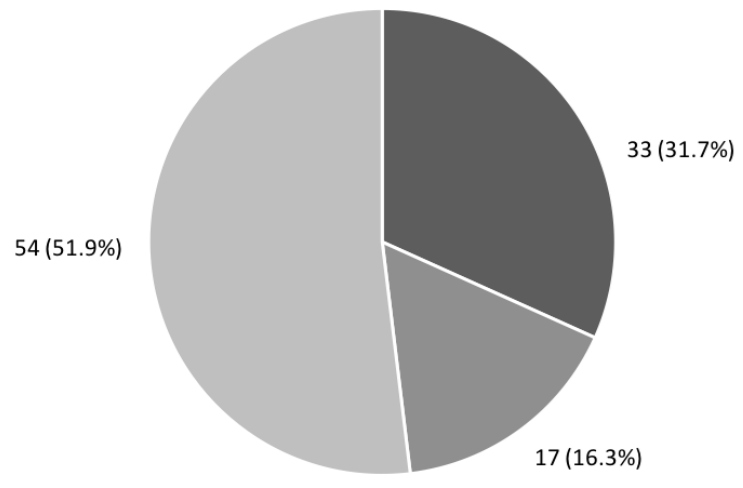

- Precedential Opinion $=$ Nonprecedential Opinion $=$ Rule 36

A final wrinkle worth exploring involves the different technology areas in which patentable subject matter disputes arise. As discussed above, the Federal Circuit's decisions on that issue fall into two broad categories: information technology (including business methods) and biotechnology (including medical diagnostics). Information technology accounts for the vast majority of decisions in our dataset: 98 out of $104 .{ }^{95}$ As Table 1 illustrates, the Federal Circuit has found the patent to be valid in only seven of those 98 decisions (7.1\%), consistent with the overall validity rate of $7.7 \%$. In biotechnology cases, though the population is small, the validity rate is also relatively low, with the court having found the patent valid in only one out of six decisions $(16.7 \%)$.

95. Though they are not a perfect fit, for simplicity, we've included in the information technology/business methods category patents on gaming methods, In re Smith, 815 F.3d at 816; In re Webb, 609 F. App’x 643, 644 (Fed. Cir. 2015), a method of cutting hair, In re Brown, 645 F. App'x 1014, 1014 (Fed. Cir. 2016), and a method and apparatus for teaching Arabic to the blind, In re Alsabah, 677 F. App'x 684, 684 (Fed. Cir. 2017), all of which the Federal Circuit found ineligible after Alice. 
TABle 1: Results of Federal Circuit Post-ALICE $§ 101$ APPEALs, BY TECHNOLOGY

\begin{tabular}{|c|c|c|c|c|}
\hline & Valid & Invalid & Total & Valid/Total \\
\hline Inforr & 7 & 91 & 98 & $7.1 \%$ \\
\hline Biotechnology & 1 & 5 & 6 & $16.7 \%$ \\
\hline
\end{tabular}

The Federal Circuit's publication practice in biotechnology cases, however, differs substantially from information technology cases, as Table 2 illustrates. The Federal Circuit has issued a precedential opinion in five of its six biotechnology-related patentable subject matter disputes. ${ }^{96}$ And the sixth decision, a Rule 36 affirmance, only qualifies as a biotechnology case because we're considering that category to include any type of medical diagnostic and the patent involved a method of determining body temperature from a measurement taken at the forehead. ${ }^{97}$ Thus, although biotechnology patents account for only $5.8 \%$ of the Federal Circuit's total decisions on patentable subject matter (six out of 104), they account for a much higher percentage of the court's precedential opinions: $15.2 \%$ (five out of 33 ).

TABle 2: Mode of Disposition of Federal Circuit Post-ALICE $\S 101$ APPEALS, BY TECHNOLOGY

\begin{tabular}{|l|r|r|r|r|r|} 
& \multicolumn{2}{|c|}{ Precedential } & Nonprecedential Rule 36 & \multicolumn{2}{|c|}{ Total } \\
\hline Information technology & 28 & 17 & 53 & 98 \\
\hline Biotechnology & 5 & 0 & 1 & 6 \\
\hline
\end{tabular}

In sum, the actual practice in the Federal Circuit looks rather different than what one would glean from simply reading the court's precedent on patentable subject matter. Patentees win much less frequently than precedent suggests. They never win in Rule 36 affirmances. And decisions involving biotechnology or medical diagnostics are rare. In the next Part, we discuss the implications of those results, provide some further analysis of our empirical data, and discuss the limitations of our study.

96. The five opinions are: Cleveland Clinic Found. v. True Health Diagnostics LLC, 859 F.3d 1352 (Fed. Cir. 2017); Rapid Litig. Mgmt. Ltd. v. CellzDirect, Inc., 827 F.3d 1042 (Fed. Cir. 2016); Genetic Techs. Ltd. v. Merial L.L.C., 818 F.3d 1369 (Fed. Cir. 2016); Ariosa Diagnostics, Inc. v. Sequenom, Inc., 788 F.3d 1371 (Fed. Cir. 2015); In re BRCA1- \& BRCA2-Based Hereditary Cancer Test Patent Litig., 774 F.3d 755 (Fed. Cir. 2014).

97. Exergen Corp. v. Sanomedics Int'l Holdings, Inc., 653 F. App'x 760 (Fed. Cir. 2016). 


\section{Does Rule 36 SKeW SUBSTANTIVE LAW?}

Patentees since Alice have done worse at the Federal Circuit than it appears from the court's precedent. While they win a respectable number of precedential decisions (albeit still a clear minority), overall they have overwhelmingly lost patentable subject matter cases on appeal. That low win rate is obscured by the procedural vehicles the court has used to decide the cases. In this Part, we consider the implications of our findings for both substantive patent law and appellate procedure.

\section{A. Is Alice an Even Bigger Deal than We Thought?}

One possible implication is that we should worry even more (or celebrate even more, depending on one's perspective) that many patents will not survive the new law of patentable subject matter. It may seem odd to suggest that patent lawyers should pay more attention to Alice; the decision has already created a whirlwind of attention in the academic and practice communities. ${ }^{98}$ Over the past year or so, however, one might have reasonably concluded that things were settling down into a less patent-hostile routine as the Federal Circuit issued several precedential opinions upholding patents against eligibility challenges. ${ }^{99}$ As noted above, those opinions drew, or at least attempted to draw, distinctions between patent claims that actually reflected (and were limited to) real technology and those that didn't. 100

98. As a small sample of post-Alice academic literature on patentable subject matter, see Dan L. Burk, The Curious Incident of the Supreme Court in Myriad Genetics, 90 NOTRE DAME L. REV. 505 (2014); Kevin Emerson Collins, Patent-Ineligibility as Counteraction, 94 WASH. U. L. REV. 955 (2017); Timothy R. Holbrook \& Mark D. Janis, Expressive Eligibility, 5 U.C. IRVINE L. REV. 973 (2015); Dmitry Karshtedt, Photocopies, Patents, and Knowledge Transfer: "The Uneasy Case” of Justice Breyer's Patentable Subject Matter Jurisprudence, 69 VAND. L. REV. 1739 (2016); Amy L. Landers, Patentable Subject Matter as a Policy Driver, 53 Hous. L. REV. 505 (2015); Jeffrey A. Lefstin, Inventive Application: A History, 67 FLA. L. REV. 565 (2015); Lisa Larrimore Ouellette, Patentable Subject Matter and Nonpatent Innovation Incentives, 5 U.C. IRVINE L. REV. 1115 (2015); Michael Risch, Nothing Is Patentable, 67 FlA. L. REV. ForUM 45 (2015); Andres Sawicki, The Central Claiming Renaissance, 103 CORNELL L. REV. (forthcoming 2018), https://ssrn.com/ abstract=2968650 [https://perma.cc/GH7U-22LB]; Symposium, Cracking the Code: Ongoing Section 101 Patentability Concerns in Biotechnology and Computer Software, 82 GEO. WASH. L. REV. 1751 (2014); David O. Taylor, Amending Patent Eligibility, 50 U.C. DAVIS L. REV. 2149 (2017).

99. See, e.g., Levy, supra note 52; see also Kevin Kabler \& Andrew Whitehead, A More Consistent USPTO Approach to Patent Eligibility, LAW360 (July 17, 2017), https://www.law360.com/articles/942429/a-more-consistent-uspto-approach-to-patent-eligibility [https://perma.cc/R9XN-LJ45] (noting that recent Federal Circuit decisions upholding patents against eligibility challenges "suggest[ ] a more consistent, and less confusing, approach to patent eligibility determination[s] may be near").

100. See supra Section I.B. 
Our data cast doubt on any suggestion about the emergence of a more balanced regime of patentable subject matter.

As Figure 11 shows, the percentage of Federal Circuit decisions finding invalidity has remained above $90 \%$ during each one-year period following Alice. Moreover, the raw number of invalidity decisions has more than doubled each year, likely reflecting the increasing frequency of successful patentable subject matter challenges in the district courts as the Supreme Court was issuing its string of decisions strengthening the eligibility requirement from 2010 to $2014 .{ }^{101}$ The reality might be even worse for patentees than our data suggest, as it seems possible that the high rates of invalidity could be deterring appeals in some cases or encouraging parties who do appeal to seek reversal on other grounds.

Figure 11: Federal CiRCUit § 101 DeCisions By YeAR

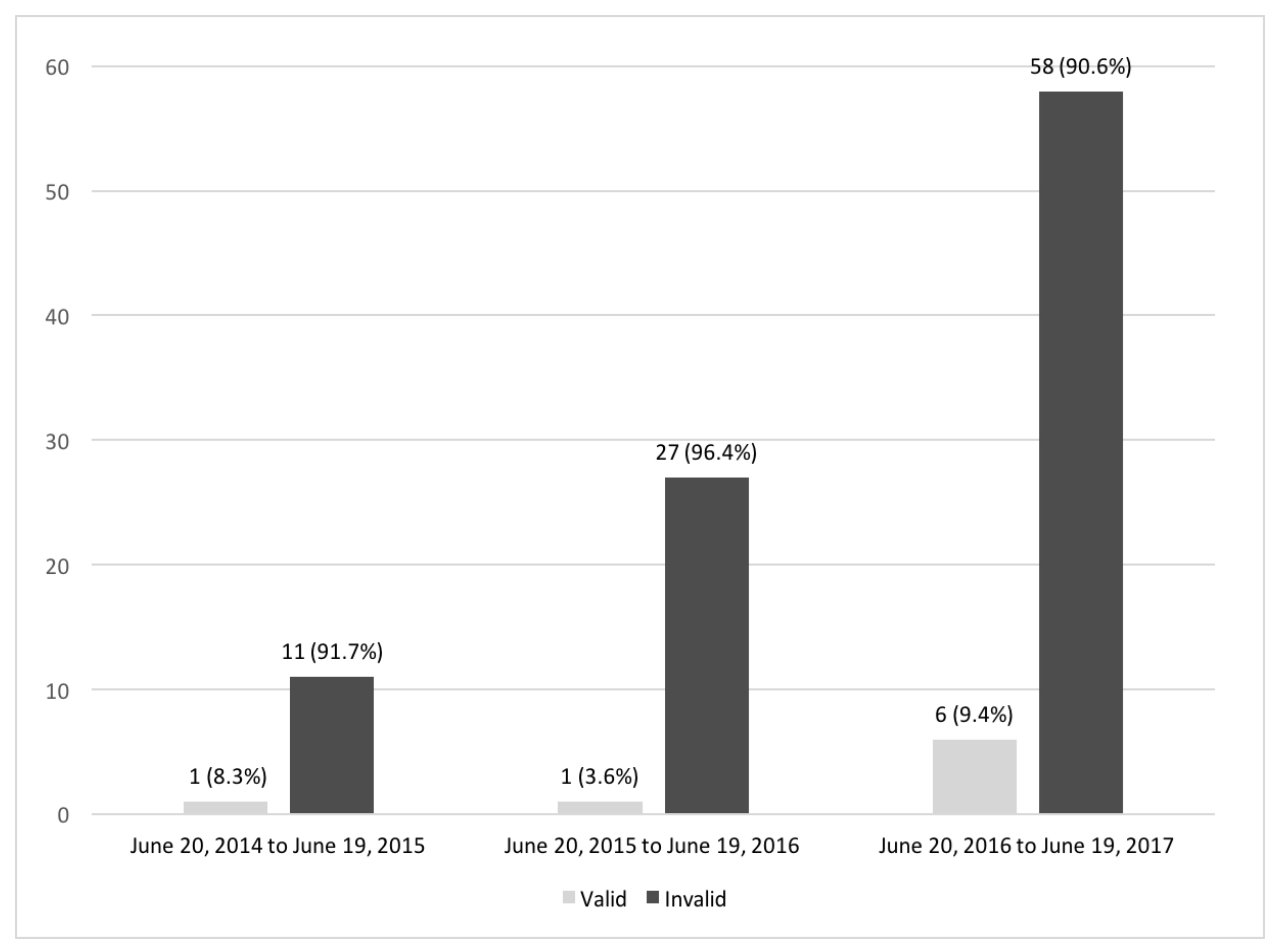

Sustained high rates of invalidity could also have significant implications for ongoing efforts at legislative reform. Influential interest groups have begun to lobby Congress to eliminate or

101. See Gugliuzza, supra note 68, at 37 (reporting that the number of pleadings-stage eligibility dismissals by district courts increased from five in 2013 to 75 in 2016). 
significantly weaken the patentable subject matter requirement. ${ }^{102}$ Our findings can't say whether that legislation is desirable. But they do indicate that relaxing or eliminating the requirement would be a major change-it would significantly affect the results of many patent disputes.

Before drawing any firm conclusions from our analysis, however, it's worth noting that our results to date may not predict the future. Almost every case the Federal Circuit has decided since Alice has been an appeal from a ruling invalidating the patent. As illustrated in Figure 9 above, in only six of the 104 cases in our dataset did the tribunal below find the patent valid, and two of those were mixed decisions upholding some claims and invalidating others. Consequently, the Federal Circuit has not had many opportunities to uphold validity, whether via Rule 36 or otherwise. That could change once the Federal Circuit hears more appeals from decisions upholding patents, particularly patents that were prosecuted after Alice when the applicant and the PTO had the benefit of knowing the new standards of patent eligibility. ${ }^{103}$

Our results might also indicate that the Federal Circuit is simply deferring on the issue of patentable subject matter to the tribunals it reviews. As Figure 12 shows, the Federal Circuit has affirmed the decision below in 94 of 104 (90.4\%) of its post-Alice decisions. Though data on the Federal Circuit's overall rates of affirmances and reversals is notoriously inconsistent, no studies put the reversal rate below the less-than-10\% figure we have found on the issue of patentable subject matter. ${ }^{104}$

102. See Dennis Crouch, AIPLA on Board with Statutory Reform of 101, PATENTLY-O (May 16, 2017), https://patentlyo.com/patent/2017/05/aipla-statutory-reform.html [https://perma.cc/9BPEPHYF] (discussing amendments to $\S 101$ proposed by the American Intellectual Property Law Association and the Intellectual Property Owners Association).

103. Cf. David L. Schwartz, Retroactivity at the Federal Circuit, 89 IND. L.J. 1547, 1549 (2014) (criticizing the Federal Circuit's practice of applying new precedent retroactively to patents that have already issued).

104. See Jason Rantanen, Empirical Analyses of Judicial Opinions: Methodology, Metrics, and the Federal Circuit, 49 CONN. L. REv. 227, 239-40 (2016) (describing studies reporting reversal rates ranging from $11 \%$ to $54 \%$ ). 


\section{Figure 12: Disposition of Federal Circuit § 101 APPEALs, Post- ALICE}

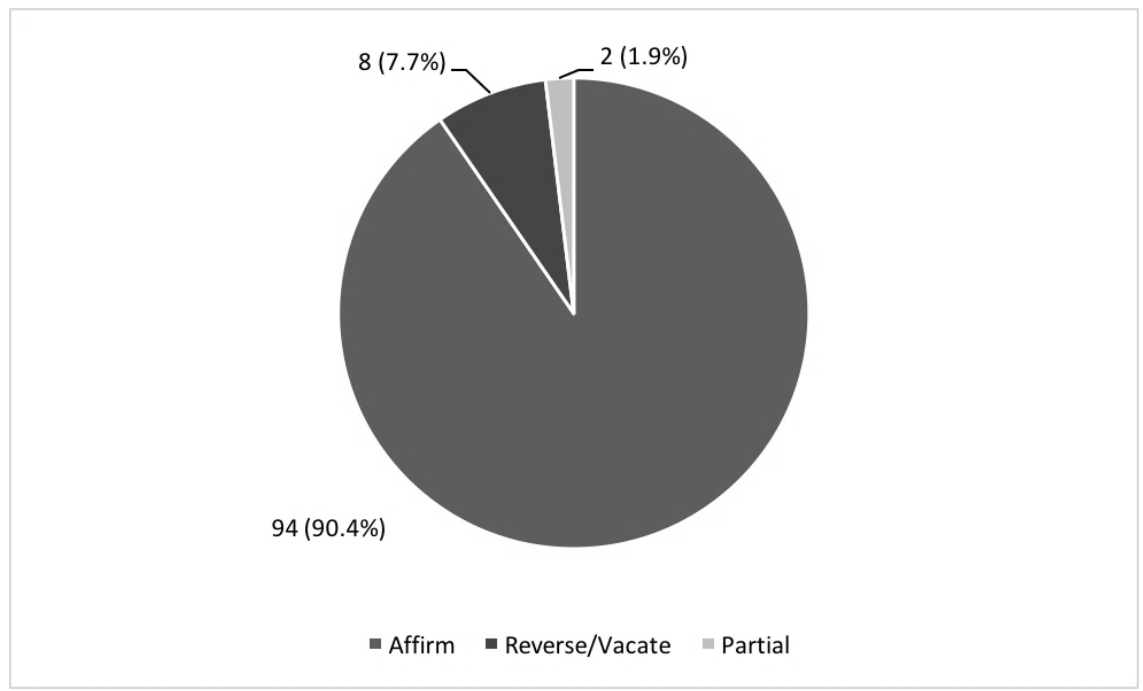

As a strictly doctrinal matter, the Federal Circuit should not be deferring to lower tribunals because patent eligibility is a question of law reviewed de novo. ${ }^{105}$ But this would not be the first time the Federal Circuit has deferred on appeal in defiance of the formal standard of review. ${ }^{106}$

If it's true that the Federal Circuit is mostly just deferring to district courts and the PTAB, we should see the patentee win rate improve if the court gets more appeals from decisions upholding patents, particularly patents prosecuted after Alice. An increase in appeals upholding patents may not occur in appeals from the PTAB

105. OIP Techs., Inc. v. Amazon.com, Inc., 788 F.3d 1359, 1362 (Fed. Cir. 2015). Contra Berkheimer v. HP Inc., 881 F.3d 1360, 1368 (Fed. Cir. 2018) (arguably creating a split within the Federal Circuit on this issue by stating that eligibility involves underlying questions of fact subject to deferential review). For a discussion of factual issues that potentially underpin the eligibility inquiry, see infra note 148.

106. See J. Jonas Anderson \& Peter S. Menell, Informal Deference: A Historical, Empirical, and Normative Analysis of Patent Claim Construction, 108 Nw. U. L. REV. 1, 6 (2013) (identifying an era of "informal deference" on the issue of claim construction based on a reversal rate of around $20 \%)$. Another possibility is that the Federal Circuit's growing caseload overall, see supra Figure 1 , is pushing the court to affirm cases more frequently across the board-a dynamic that appears to exist on other courts of appeals. See Bert I. Huang, Lightened Scrutiny, 124 HARV. L. REv. 1109, 1115 (2011) (discussing the Second Circuit). For a detailed analysis of how inattention to formal standards of review can cause systemic doctrinal shifts, see Jonathan S. Masur \& Lisa Larrimore Ouellette, Deference Mistakes, 82 U. CHI. L. REV. 643 (2015). 
because of the peculiarities of the administrative process, ${ }^{107}$ but it could occur in cases appealed from district courts, which account for the vast majority of patentable subject matter decisions (88 out of 104) in our dataset. District court decisions overall are not nearly as likely to find invalidity as the decisions we analyze. ${ }^{108}$ What the Federal Circuit has seen in the three years since Alice are primarily rulings that occurred pretrial. Many defendants have challenged patents under Alice on a motion to dismiss or an early summary judgment motion. ${ }^{109}$ If those motions are granted, the case is generally over and an appeal follows. By contrast, if the district court denies the motion, the case will continue in the district court, either to trial or, more frequently, to a settlement. So cases in which the district court grants an Alice motion are more likely to be appealed, and will be appealed sooner, than cases upholding the patent. Lastly, one might reasonably infer that the patents challenged on eligibility grounds in the immediate wake of Alice have been those that were most obviously invalid. ${ }^{110}$ Once those easy invalidations are finished (and once patentees are deterred from

107. Several factors make it unlikely that the Federal Circuit will hear many appeals challenging PTAB rulings confirming validity. To begin with, the PTAB accounts for a small fraction of Federal Circuit decisions on patentable subject matter-only 16 of the 104 decisions in our dataset. Most of those PTAB decisions (10 out of 16) originated in the covered business method review program, which may not exist in two years. See America Invents Act, Pub. L. No. 112-29, $\S 18(a)(3), 125$ Stat. 284, 330-31 (2011) (sunset provision). Also, for a patent to even enter the covered business method review program, the PTAB must have determined that it is "more likely than not" that at least one claim of the patent is invalid, 35 U.S.C. § 324(a) (2012); America Invents Act $\S 18(a)(1), 125$ Stat. at 329-30, which means that any patent entering the program is probably doomed. (And if the PTAB refuses to institute the proceeding, effectively upholding validity, that decision is not appealable. 35 U.S.C. §324(e).) Moreover, patentable subject matter cannot be challenged in the most popular PTAB proceeding, inter partes review. See id. §311(b) (permitting review only on the grounds of anticipation and obviousness). Although the PTAB can consider patentable subject matter in the new post-grant review proceeding, see id. §321(b), it's not yet clear how extensively that proceeding will be used because of the stringent timeline for filing a petition and statutory estoppel provisions that require accused infringers to forgo certain invalidity arguments in any future infringement litigation. See Gugliuzza, supra note 82, at 28284. The PTO will, of course, continue to consider the patentable subject matter requirement during examination, but appeals from examination consist entirely of decisions rejecting applications for failure to satisfy patentability requirements; decisions approving a patent application cannot be appealed. See Jonathan Masur, Patent Inflation, 121 YALE L.J. 470, 474 (2011); Melissa F. Wasserman, The PTO's Asymmetric Incentives: Pressure to Expand Substantive Patent Law, 72 OHIO ST. L.J. 379, 385 (2011). Thus, if the Federal Circuit is going to hear more appeals upholding eligibility, those appeals will likely come from the district courts.

108. See Jeffrey A. Lefstin et al., Final Report of the Berkeley Center for Law \& Technology Section 101 Workshop: Addressing Patent Eligibility Challenges, 32 BERKELEY TECH. L.J. (forthcoming 2018) (manuscript at 22), https://ssrn.com/abstract=3050093 [https://perma.cc/Y5RW-VBWE] (reporting a $61.8 \%$ invalidity rate in the district courts from June 2014 to February 2017).

109. See id. at 23 (reporting that, from June 2012 to February 2017, 69.4\% of district court decisions on eligibility (249 of 359) were made on a motion to dismiss or for judgment on the pleadings and that another $27.0 \%$ (97 of 359) were made on a motion for summary judgment).

110. See Gugliuzza, supra note 68, at 46. 
asserting patents similar to the ones invalidated), patentee win rates might begin to increase.

In short, our dataset is relatively small and is overwhelmingly composed of appeals from decisions of invalidity. As the composition of appeals changes, so might our results.

\section{B. Is the Federal Circuit Changing the Law Through the Way It Decides Cases?}

The fact that most Federal Circuit decisions invalidating patents under Alice-but none of the decisions upholding patents-are hidden from view by Rule 36 may affect the long-term development of the law. ${ }^{111}$

We would be most concerned if there were reason to think the Federal Circuit was deliberately skewing perceptions about the results of patentable subject matter cases by promoting decisions finding patents valid and demoting decisions finding them invalid. The Federal Circuit is, of course, not a monolithic entity, which makes it unlikely that the court as a whole has intentionally tried to distort perceptions of the law. That said, it is possible that individual judges might be inclined not to write or to join opinions endorsing positions they dislike, even if they feel compelled to vote in a certain way because of Supreme Court precedent. ${ }^{112}$

To test for these possibilities, we collected information on how each Federal Circuit judge voted in each post-Alice patentable subject matter case in our dataset. We then compared each judge's propensity to vote in favor of validity on patentable subject matter to the judge's

111. Some have expressed another concern — that the court is not actually paying as much attention to Rule 36 cases as it does to those in which it writes opinions. See Gene Quinn \& Peter Harter, Rule 36, Collateral Estoppel and Unequal Treatment at the Federal Circuit, IPWATCHDOG (Apr. 25, 2017), http://www.ipwatchdog.com/2017/04/25/rule-36-collateral-estoppel-unequaltreatment-federal-circuit/id=82480/ [https://perma.cc/7PS7-UHUA] ("When you don't have to show your work how can you or anyone else really be sure that the decision is fair, done after a full consideration of the issues presented and arguments made, and without making a mistake?"). We aren't particularly concerned by this. The Federal Circuit has noted that Rule 36 judgments "receive the full consideration of the Court of Appeals, and are no less carefully decided than the cases in which [the court] issues full opinions." Phil-Insul Corp. v. Airlite Plastics Co., 854 F.3d 1344, 1354 (Fed. Cir. 2017). The fact that a case is not selected for Rule 36 affirmance until after bench memos are written and oral argument is held, unlike the practice in many other circuits, makes the court's statement credible. While it's true that writing an opinion can sometimes surface issues that might otherwise go unnoticed, that is likely to be rare when the district court opinion, briefing, and oral argument have all failed to raise those issues. The question of hiding complex issues in Rule 36 cases, as opposed to finding the case easy to decide under existing law, is potentially more problematic; we take it up below. See infra Section III.B.

112. See Ben Grunwald, Strategic Publication, 92 TUL. L. REV. (forthcoming 2018) (on file with authors) (documenting the phenomenon of concealing disagreement on the merits by not publishing the resulting opinion in the regional circuits). 
propensity to cast a vote invalidating a patent on that ground in a Rule 36 affirmance. The hypothesis is that judges who are more likely to vote to uphold validity are also more likely to cast invalidity votes in "hidden" decisions under Rule 36 as opposed to written opinions. We present our results in Tables 3 and 4 and Figures 13 and 14.

Table 3 lists, for each active Federal Circuit judge, the raw number of their "valid" and "invalid" votes in post-Alice cases involving $\S 101$ 's patentable subject matter requirement, as well as the percentage of their total $\S 101$ votes that are "valid" votes. ${ }^{113}$ As Table 3 illustrates, Judge Newman has the strongest propensity to uphold a patent, having voted in favor of validity in three out of 15 decisions (20\%). At the other end, Judges Lourie and Dyk have not cast a single vote in favor of validity since Alice.

TABle 3: Federal Circuit Judges' Votes In Post-ALICE $§ 101$ DECISIONS

\begin{tabular}{|l|r|r|r|}
\hline Judge & Valid & \multicolumn{1}{|c|}{ Invalid } & Valid/Total \\
\hline Newman & 3 & 12 & $20.0 \%$ \\
\hline Stoll & 3 & 17 & $15.0 \%$ \\
\hline Wallach & 3 & 23 & $11.5 \%$ \\
\hline Moore & 3 & 26 & $10.3 \%$ \\
\hline O'Malley & 2 & 18 & $10.0 \%$ \\
\hline Chen & 2 & 18 & $10.0 \%$ \\
\hline Taranto & 2 & 20 & $9.1 \%$ \\
\hline Prost & 1 & 21 & $4.5 \%$ \\
\hline Reyna & 1 & 22 & $4.3 \%$ \\
\hline Hughes & 1 & 28 & $3.4 \%$ \\
\hline Dyk & 0 & 18 & $0.0 \%$ \\
\hline Lourie & 0 & 21 & $0.0 \%$ \\
\hline
\end{tabular}

Table 4 then lists, again for each active judge, the raw number of their invalid votes in $\S 101$ cases, the number of those votes that were cast in cases decided via Rule 36, and the percentage of each judge's invalid votes cast via Rule 36 .

113. In this initial analysis of voting data, we exclude visiting judges and judges who were on senior status as of the end of our collection period. We discuss below how our results change if we include the votes of some of those judges. See infra notes 117-119 and accompanying text. 
TABle 4: Federal Circuit Judges' Invalidity Votes in Post-ALiCE $\S 101$ DECISIONS

\begin{tabular}{|l|r|r|r|}
\hline Judge & Invalid & Rule 36 & Rule 36/Invalid \\
\hline Newman & 12 & 9 & $75.0 \%$ \\
\hline O'Malley & 18 & 13 & $72.2 \%$ \\
\hline Hughes & 28 & 18 & $64.3 \%$ \\
\hline Moore & 26 & 16 & $61.5 \%$ \\
\hline Taranto & 20 & 12 & $60.0 \%$ \\
\hline Wallach & 23 & 13 & $56.5 \%$ \\
\hline Dyk & 18 & 10 & $55.6 \%$ \\
\hline Stoll & 17 & 9 & $52.9 \%$ \\
\hline Lourie & 21 & 11 & $52.4 \%$ \\
\hline Chen & 18 & 9 & $50.0 \%$ \\
\hline Reyna & 22 & 10 & $45.5 \%$ \\
\hline Prost & 21 & 8 & $38.1 \%$ \\
\hline
\end{tabular}

Though the number of total $\S 101$ votes by any given judge is relatively small (a maximum of 29 and a minimum of 15 , as one can calculate from Table 3), some possibility of correlation between overall voting behavior on $\S 101$ and mode of disposition is apparent, at least for particular judges. For example, Judge Newman-who, again, is the judge most likely to vote in favor of validity-is also the judge most likely to cast a vote of invalidity via Rule 36, having cast 9 out of her 12 invalid votes $(75 \%)$ in that fashion. At the other end, Chief Judge Prost-who, as Table 3 illustrated, is among the least likely to vote in favor of validity, having done so in only 1 out of 22 cases $(4.5 \%)$-is also the least likely to cast an invalidity vote via Rule 36 , having cast only 8 of her 21 invalid votes (38.1\%) in that fashion. Both of those examples are consistent with a hypothesis that judges' overall voting propensity on $\S 101$ may predict their use of Rule 36 .

To that end, it's interesting to note that, on the Federal Circuit, the panel's presiding judge assigns authorship responsibility ${ }^{114}$ and that Judges Newman and Prost are either extremely likely (Newman) or guaranteed (Prost) to be the presiding judge on any panel. As chief, Judge Prost presides on any panel on which she sits. As the senior-most active judge, Judge Newman presides on any panel that does not 
include Chief Judge Prost.115 Thus, Judges Newman and Prost exert significant influence over the mode of disposition in cases in which they participate. The (admittedly limited) data we have gathered suggest that they could, in fact, be using that influence to implement preferences to dispose of cases reaching particular results in particular ways. ${ }^{116}$

To test our hypothesis more formally, we ran a simple linear regression asking whether a judge's propensity to cast an invalidity vote on $\S 101$ via Rule 36 might be explained by the judge's overall propensity to vote in favor of validity on that issue. Figure 13 reflects our results. ${ }^{117}$

115. Id. at 1.2 .

116. In a similar vein, evidence from other circuits suggests that judges in the minority on an issue will sometimes agree to unanimity in exchange for issuing the decision without an opinion. See Mitu Gulati \& C.M.A. McCauliff, On Not Making Law, 61 LAW \& ConTEMP. Probs. 157, 192 93 (1998). It should be noted that the norm of allowing the panel's more junior judges to speak first at conference, a norm we understand the Federal Circuit to follow, could partly reduce the presiding judge's influence over the mode of disposition. And, to be clear, strategic behavior is not the only explanation for our results (or even the most likely one). See generally infra Section III.C. For example, one might note that Judge Newman's general propensity to uphold validity means that the only patents she would vote to invalidate are those that are most plainly invalid and therefore most appropriate for Rule 36 treatment by the terms of the rule itself. But a similar explanation about the faithful application of Rule 36 would not necessarily hold for judges such as Chief Judge Prost whose propensities tilt the opposite direction-likely to invalidate and unlikely to use Rule 36 to do so. If a judge thought that most patents challenged under $\S 101$ were obviously invalid, we might expect that judge to use Rule 36 a lot, too, since the judge would view many $§ 101$ cases to be easy ones. Yet we see the opposite-judges who tend to think most patents challenged under $\S 101$ are invalid also generate a lot of precedent to support their view.

117. We report the full results of our regression analysis in Appendix B. 
Figure 13: RELATIONSHIP BETWEen § 101 Votes AND USE OF RULE 36 FOR ACTIVE FEDERAL CIRCUIT JUDGES

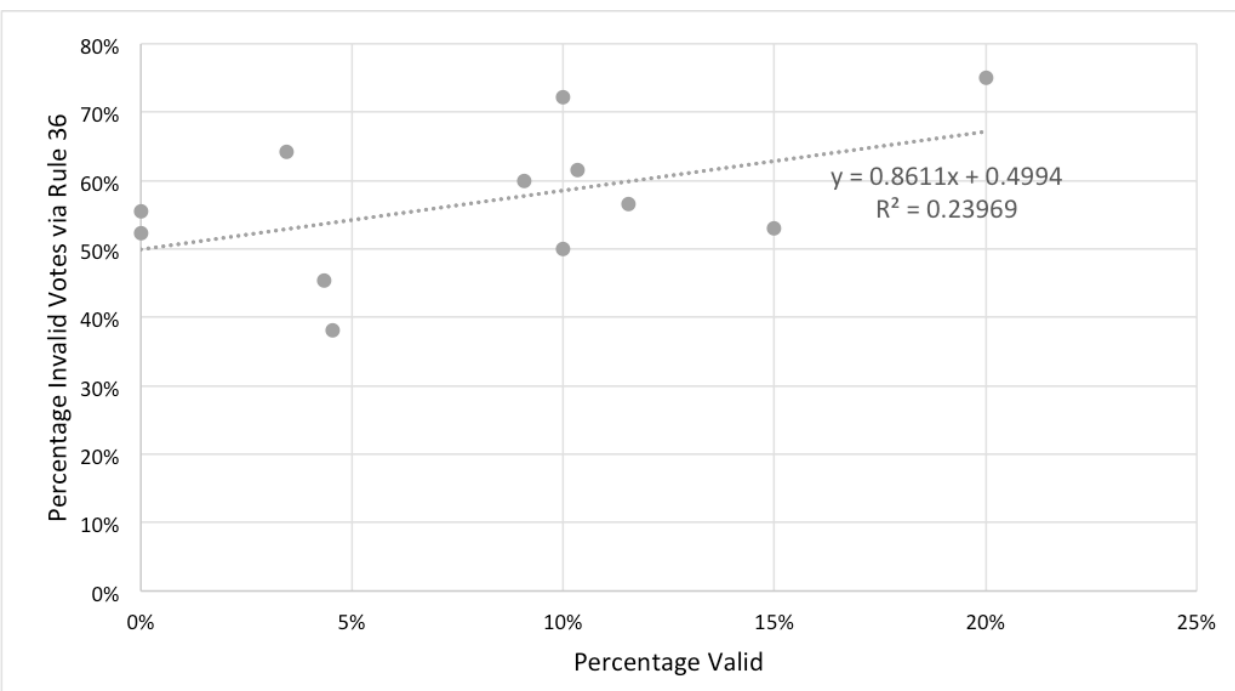

As the data suggest, there is a modest correlation, with a judge's propensity to vote in favor of validity on $\S 101$ explaining $24 \%$ of the odds that a post-Alice $\S 101$ decision will be disposed of via opinion or Rule 36. Though the correlation is not statistically significant ( $p=$ 0.106), that changes if we expand our dataset to include the votes of judges who are not active Federal Circuit judges but who have cast 10 or more votes in post-Alice $\S 101$ cases. In total, eight judges who are not active Federal Circuit judges have cast votes in those cases. Those eight judges account for 45 of the 311 total votes in our dataset. ${ }^{118}$ Two of those eight judges have cast 10 or more votes: Judges Bryson (11 votes, all invalid, six via Rule 36) and Mayer (10 votes, all invalid, four via Rule 36), both of whom are Federal Circuit judges on senior status. None of the other six judges have cast more than seven votes. ${ }^{119}$ If we include Judges Bryson and Mayer in our regression, the correlation becomes statistically significant at a $5 \%$ level $(p=0.043)$, with a judge's propensity to vote in favor of validity on $\S 101$ now explaining $30 \%$ of

118. For a full list of the votes cast in $\S 101$ cases by judges who are not active Federal Circuit judges, see infra Appendix C.

119. Interestingly, only one of the 45 total votes cast by judges who are not active Federal Circuit judges was a vote to uphold validity. See Amdocs (Isr.) Ltd. v. Openet Telecom, Inc., 841 F.3d 1288, 1290 (Fed. Cir. 2016) (Senior Judge Plager, writing the opinion for the court). 
the odds that a post-Alice $\S 101$ decision will be disposed of via opinion or Rule $36 .{ }^{120}$ Figure 14 reflects this analysis.

FigURE 14: RELATIONSHIP BETWEeN § 101 Votes AND USE OF RULE 36 FOR ACTIVE FEDERAL CiRCUIT Judges Plus Judges BRYson AND

MAYER

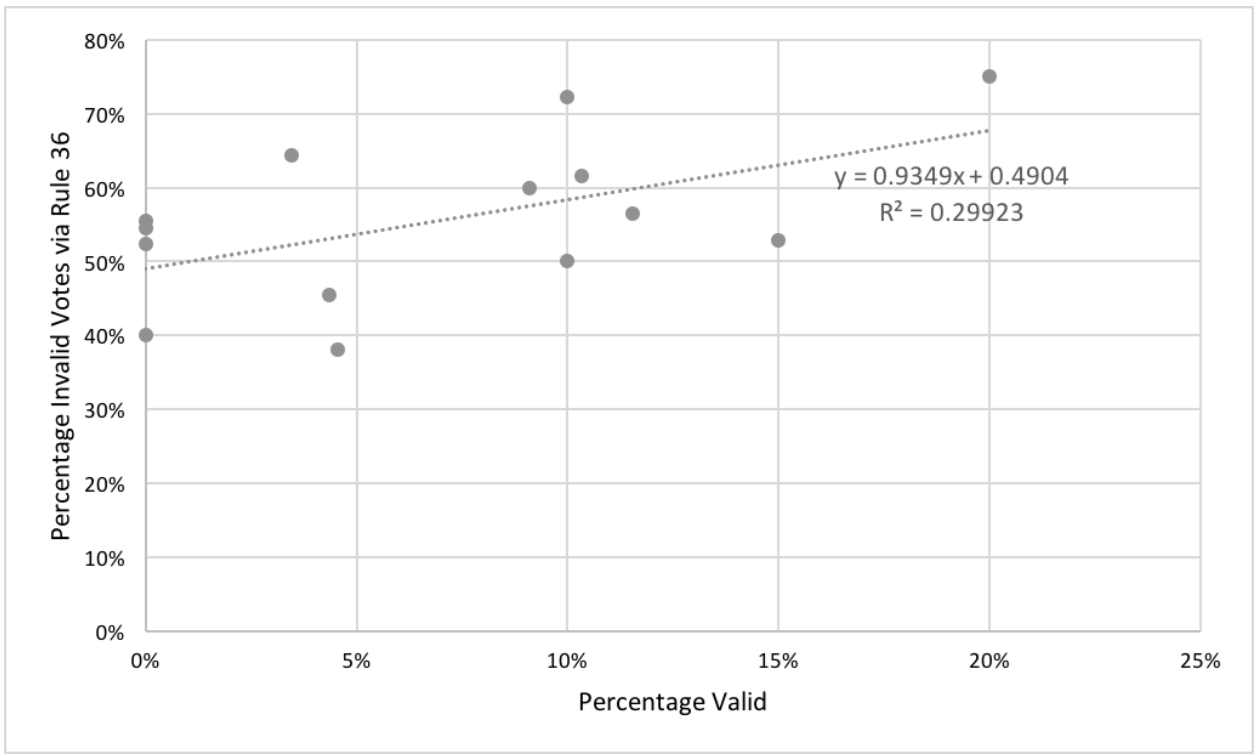

In short, though it is hard to draw firm conclusions about the relationship between overall voting behavior and the propensity to use Rule 36, the limited evidence available post-Alice is intriguing and warrants close attention going forward, as a larger number of decisions will permit more robust statistical analysis. ${ }^{121}$

120. For the full results of this revised regression analysis, see infra Appendix D. It's also worth noting that the two active judges who appear to be outliers, Judge Newman and Chief Judge Prost, play a key role in fueling the overall correlation between voting propensity on validity under $\S 101$ and propensity to participate in Rule 36 affirmances. If those judges are removed from the regression (and Judges Bryson and Mayer are also omitted), the R-square decreases to 0.027 and the p-value increases to 0.65 . For the full results of that regression analysis, see infra Appendix E.

121. One final note: though our dataset contains 104 decisions, it contains only 311 votes, not the 312 votes one would expect from 104 decisions by panels of three judges, because one case was decided by a two-judge panel. buySAFE, Inc. v. Google, Inc., 765 F.3d 1350, 1351 (Fed. Cir. 2014). Also, one vote was a mixed vote to find some claims valid and others invalid. Intellectual Ventures I LLC v. Symantec Corp., 838 F.3d 1307, 1329 (Fed. Cir. 2016) (Stoll, J., dissenting in part). To avoid complications, we have excluded that one mixed vote from the preceding analysis of individual judges' voting data. 
Another interesting question is how the court's use of Rule 36 in patentable subject matter cases compares to its use of Rule 36 in other areas of law. ${ }^{122}$ As shown in Figure 10 above, the court has decided $51.9 \%$ of its post-Alice patentable subject matter appeals through Rule 36 affirmances, $31.7 \%$ through precedential opinions, and $16.3 \%$ through nonprecedential opinions. Figure 15 below provides data on the mode of disposition for all Federal Circuit appeals (including patentable subject matter cases) from the district courts and the PTO in the threeyear period following Alice. As that figure shows, the court has overall decided only $41.7 \%$ of its cases through Rule 36 affirmances-10\% less than in patentable subject matter cases alone.

\section{Figure 15: Mode of Disposition of All Federal CiRCUit APPEALS FROM DISTRICT COURTS AND THE PTO, POST-ALICE}

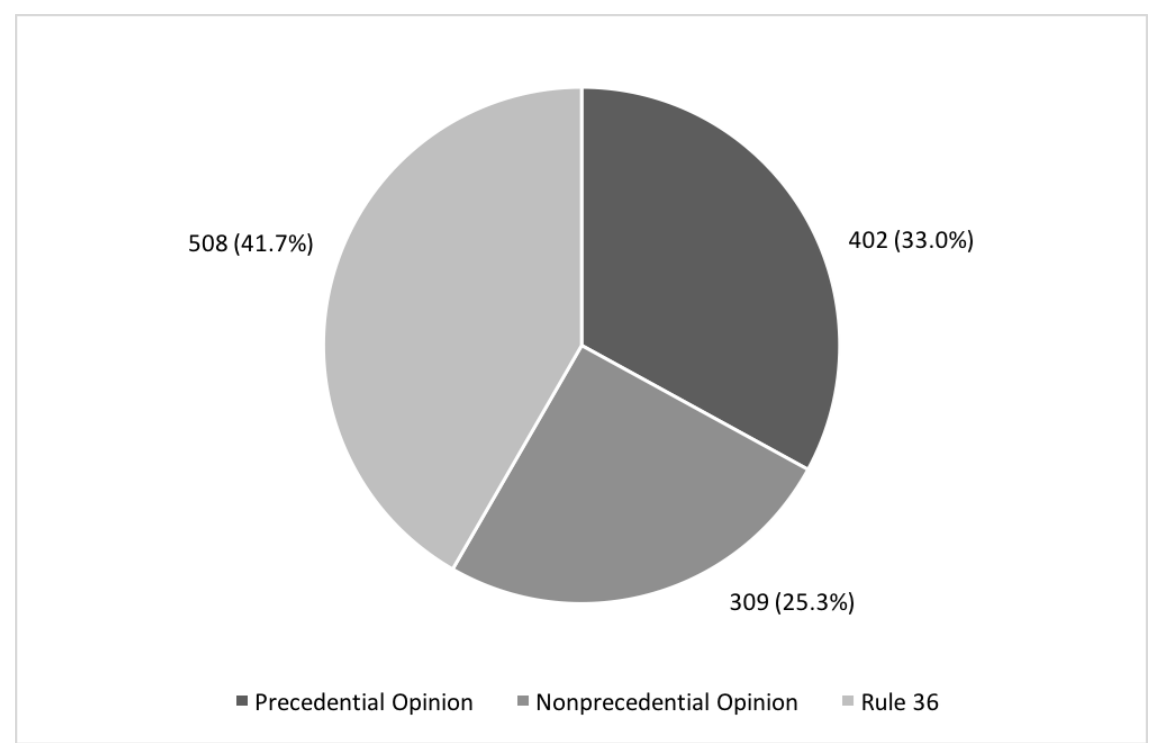

At first blush, a 10 percentage point difference might not seem consequential. For several reasons, however, it's actually quite

122. Previous studies have performed this comparison for other issues of patent doctrine. Notably, then-professor (now Federal Circuit judge) Kimberly Moore studied Federal Circuit claim construction decisions in the wake of Markman v. Westview Instruments, Inc., 517 U.S. 370,372 (1996) (holding that the judge, not the jury, must interpret the claims of the patent), and found that the court used Rule 36 less frequently than in other types of cases, "despite the intuition that [claim construction decisions] would be the least likely to have precedential value." Moore, supra note 2, at 237. Moore also found that, once Rule 36 affirmances were taken into account, the Federal Circuit's reversal rate in claim construction appeals was lower than previous studies had suggested. Id. at 235-37. 
surprising to find that the Federal Circuit uses Rule 36 with greater frequency in patentable subject matter cases than in other types of cases. First, almost all patentable subject matter appeals come from district courts, ${ }^{123}$ not the PTAB, and the Federal Circuit is, overall, much less likely to use Rule 36 in appeals from district courts as opposed to the PTAB. In 2016, the Federal Circuit used Rule 36 to resolve $50.5 \%$ of PTO appeals overall. ${ }^{124}$ By contrast, the Federal Circuit disposed of only $35.6 \%$ of district court appeals via Rule 36 , and that number would be smaller still if we excluded patentable subject matter cases, where the Federal Circuit uses Rule 36 with a higherthan-average frequency. ${ }^{125}$

Second, Rule 36 is commonly used in circumstances in which the Federal Circuit is deferring to the finder of fact. ${ }^{126}$ Indeed, deference to fact-finding underlies the first two bases listed in Rule 36 for entering a judgment without opinion. ${ }^{127}$ But patentable subject matter is a question of law reviewed without deference. ${ }^{128}$

Finally, many Rule 36 decisions outside the patentable subject matter context come in well-settled areas of law like novelty and nonobviousness that are the subject of dozens or hundreds of precedential decisions, so the incremental benefit of one additional opinion is small. Other types of disputes ripe for Rule 36 treatment involve questions of claim construction or infringement that are highly case specific and offer little precedential value. ${ }^{129}$ In patentable subject matter, by contrast, courts are making the law as they go. And the common law, "I know it when I see it" nature of post-Alice doctrine ${ }^{130}$ means that providing additional signposts for lawyers could be more important here than in other fields.

123. Eighty-eight of the 104 cases in our dataset. See supra notes 107-108 and accompanying text.

124. See supra Figures 2-3.

125. In 2016, the Federal Circuit used Rule 36 to dispose of $55.0 \%$ (22 of 40 ) of its patentable subject matter appeals from district courts. See infra Appendix A.

126. See Rachel Hughey, How to Get to Federal Circuit Rule 36, LAW360 (July 29, 2015), https://www.law360.com/articles/684264/how-to-get-to-federal-circuit-rule-36 [https://perma.cc/ UR6Q-BNXY] (suggesting that, to obtain a Rule 36 affirmance, "an appellee should urge that the case hinges on the facts and is entitled to a highly deferential standard of review").

127. See FED. CIR. R. 36(a)-(b) ("The court may enter a judgment of affirmance without opinion, citing this rule, when it determines that any of the following conditions exist and an opinion would have no precedential value: (a) the judgment, decision, or order of the trial court appealed from is based on findings that are not clearly erroneous; [or] (b) the evidence supporting the jury's verdict is sufficient ....").

128. See supra note 105.

129. See supra note 122.

130. Eclipse IP LLC v. McKinley Equip. Corp., No. CV 14-154, 2014 WL 4407592, at *3 (C.D. Cal. Sept. 4, 2014) (Wu, J.) (quoting Jacobellis v. Ohio, 378 U.S. 184, 197 (1964) (Stewart, J., concurring)). 


\section{The Proper Role of Rule 36}

Our findings about the Federal Circuit's use of Rule 36 in patentable subject matter cases also have implications for the ongoing debate over whether Rule 36 is wise or lawful. The dispute over the Rule's legality centers on 35 U.S.C. $\S 144$, which provides that the Federal Circuit, after deciding an appeal from the PTO, "shall issue to the Director its mandate and opinion." 131 The argument that Rule 36 is unlawful is that $\S 144$ requires the Federal Circuit to issue an opinion in every case appealed from the PTO. ${ }^{132}$

We won't dwell long on the legal argument because $\S 144$ applies only to appeals from the PTO and, as noted, most patentable subject matter appeals arise from the district courts. But there are reasons to be skeptical of any argument that Rule 36 is illegal. For starters, appellate courts have, for better or worse, long engaged in the practice of affirming without writing an opinion. ${ }^{133}$ In fact, since 1967, Rule 36 of the Federal Rules of Appellate Procedure has explicitly authorized the federal courts of appeals to render judgment with no opinion. ${ }^{134}$ As the Supreme Court recently held in a decision involving the patent venue statute, if Congress wants to overturn a settled practice of the federal courts, it must make its intent clear in the text of the statute. ${ }^{135}$ We doubt the relevant language of $\S 144$ would pass that bar. It doesn't explicitly require an opinion in every case. And it was enacted in 1984, nearly two decades after the enactment of Appellate Rule 36 and at a time by which the practice of issuing decisions without opinion was well established as a general matter, ${ }^{136}$ even if the practice had not yet caught on in the Federal Circuit, ${ }^{137}$ which, at the time, was barely two years old.

131. 35 U.S.C. $\S 144$ (2012) (emphasis added).

132. See Crouch, supra note 4 , at 562.

133. See, e.g., Philip Marcus, Affirmance Without Opinion, 6 FordHAM L. REv. 212, 213-14 (1937); Max Radin, The Requirement of Written Opinions, 18 CALIF. L. REV. 486, 491 (1930). But cf. Daniel J. Meador et al., Appellate Courts: Structures, Functions, Processes, and PERSONNEL 561 (2d ed. 2006) (outlining divergent practices among the various federal and state appellate courts).

134. FED. R. APP. P. 36(a) ("A judgment is entered when it is noted on the docket. The clerk must prepare, sign, and enter the judgment: (1) after receiving the court's opinion-but if settlement of the judgment's form is required, after final settlement; or (2) if a judgment is rendered without an opinion, as the court instructs." (emphasis added)).

135. TC Heartland LLC v. Kraft Foods Grp. Brands LLC, 137 S. Ct. 1514, 1520 (2017) ("When Congress intends to effect a change of that kind, it ordinarily provides a relatively clear indication of its intent in the text of the amended provision.").

136. See Dowd, supra note 4, at 34-42 (recounting the legislative history of the amendment).

137. See Crouch, supra note 4, at 568 (noting that the Federal Circuit adopted Rule 36 in 1989). But see Dowd, supra note 4, at 44 (noting that one of the Federal Circuit's predecessors, the Court 
Even assuming the Federal Circuit is legally permitted to dispose of over half of its patentable subject matter cases without an opinion, there remains a policy question about whether that practice is good for the patent system. On one hand, the Alice inquiry is a common law, fact-specific analysis, and examples are probably the best way to flesh out the contours of the test. On the other hand, the Federal Circuit's time and energy are finite. The court's frequent use of Rule 36 might demonstrate merely that it views many $\S 101$ appeals as easy cases given the Supreme Court's obvious skepticism of software and business method patents, which account for the overwhelming majority of patentable subject matter challenges decided by the Federal Circuit. ${ }^{138}$ More examples might be useful, but the judges of the Federal Circuit should have some discretion about where to direct their opinionwriting efforts.

One might, of course, view the disproportionate number of precedential opinions upholding validity as evidence of the court trying to undermine Supreme Court precedent hostile to patentees. Indeed, our data suggest the possibility that individual judges could use Rule 36 to counteract that precedent. But one could just as easily view the Federal Circuit's tendency to write precedential opinions when upholding patents as reflecting an intermediate appellate court that is simply doing its job in implementing the somewhat ambiguous eligibility decisions the Supreme Court has issued. Viewed through that lens, the Federal Circuit, by writing precedential opinions upholding validity that can be compared to the large body of precedent invaliding patents on eligibility grounds, is providing something similar to the percolation that occurs among the various regional courts of appeals in other areas of law. ${ }^{139}$ And even if one characterized the Federal Circuit as trying to resist Supreme Court precedent, any resistance is having only a modest effect-nearly $80 \%$ of the Federal Circuit's precedential opinions still invalidate the asserted patent.

Rather than resistance by the Federal Circuit, two other considerations more likely explain the disproportionate number of precedential opinions upholding validity. First, because of the high rate of invalidity in the tribunals it reviews, the Federal Circuit has had few

of Customs and Patent Appeals, occasionally issued very short affirmances with practically no substantive reasoning).

138. See supra Tables 1-2.

139. See Rochelle Cooper Dreyfuss, What the Federal Circuit Can Learn from the Supreme Court-and Vice Versa, 59 Am. U. L. REv. 787, 795 (2010); Paul R. Gugliuzza, Saving the Federal Circuit, 13 ChI.-Kent J. InTell. Prop. 350, 352-64 (2014); see also J. Jonas Anderson, Patent Dialogue, 92 N.C. L. REV. 1049, 1094 (2014) (exploring the benefits of a "dialogic" relationship among the Federal Circuit, the Supreme Court, and Congress on matters of patent law). 
opportunities to even consider affirming a ruling of validity via Rule 36 . Because findings of invalidity on patentable subject matter are the norm in district courts and at the PTAB, a Federal Circuit decision affirming invalidity is hardly surprising and is therefore more likely to warrant an opinionless or nonprecedential disposition under the Federal Circuit's governing rules. By contrast, a decision upholding a patent against a patentable subject matter challenge is more unusual and thus more likely to warrant a precedential opinion. ${ }^{140} \mathrm{As}$ we showed in Tables 1 and 2, information technology cases striking down patents are not uncommon, but biotechnology cases of any sort are uncommon, which would explain the court's practice of writing precedential opinions in practically every biotechnology case its sees while frequently affirming via Rule 36 in the information technology cases that compromise the bulk of the Federal Circuit's $\S 101$ docket.

Second, by writing a precedential opinion in nearly every case in which it finds a patent to be valid, the court is also responding to the demands of its audience, as a semi-specialized court such as the Federal Circuit might be expected to do. ${ }^{141}$ Alice, decided in June 2014, was the fourth Supreme Court decision in four years ruling against the patentee on patentable subject matter. By the time the Federal Circuit issued its first post-Alice opinion upholding validity in December $2014,{ }^{142}$ the Federal Circuit's audience - patent applicants, litigants, district judges, and the PTO-desperately needed examples of inventions that remained patent eligible. An ongoing desire for examples is clear from the frequent guidance that the PTO issues to its examining corps (and that is widely read by patent practitioners) after many precedential Federal Circuit decisions on patentable subject matter. ${ }^{143}$ The examples provided by the Federal Circuit's precedential opinions are also critically important to practice on the ground. The PTO, for instance, has instructed its examiners that they should not reject an application

140. A similar but more general observation relates to the fact that, to invalidate a patent, the court needs to find only one good argument against validity, so if there's an easy argument for invalidity, the court can ignore the hard issues. To uphold validity, by contrast, the court must consider every argument the challenger raises and reject it. Because a decision upholding validity must engage the hard issues, it's more likely that such a decision would merit a precedential opinion.

141. See BAUM, supra note 6 , at 99.

142. DDR Holdings, LLC v. Hotels.com, L.P., 773 F.3d 1245 (Fed. Cir. 2014).

143. The PTO's extensive library of patentable subject matter guidance is available at Subject Matter Eligibility, U.S. PAT. \& TRADEMARK OFF., https://www.uspto.gov/patent/laws-andregulations/examination-policy/subject-matter-eligibility (last visited Jan. 19, 2018) [https://perma.cc/7JBD-RB7A]. 
for claiming an abstract idea unless the claimed invention is similar to something the courts have previously identified as an abstract idea. ${ }^{144}$

The Federal Circuit's sensitivity to its audience's need for examples is clearest in biotechnology cases. Uncertainty over patentability flourished in that field after Mayo. ${ }^{145}$ Yet the court has received few biotechnology appeals to date, so it has capitalized on every opportunity it has had to provide guidance to the bar, the district courts, and the PTO.

In short, the Federal Circuit has, in its precedential opinions, delivered the types of examples its audience needed. But those opinions now provide an inaccurate picture of how disputes over patentable subject matter are actually resolved. ${ }^{146}$

It's tough to say whether the disproportionate number of precedential decisions favoring patentees has actually skewed substantive law. On one hand, as shown in Figures 8 and 9, the rates of invalidity in the Federal Circuit and in the decisions appealed to the Federal Circuit are both over 90\%, suggesting that the Federal Circuit, district courts, and the PTAB are applying the patentable subject matter requirement in a consistent fashion. As we also noted, however, the actual invalidity rate in the district courts is lower-some evidence suggests it's around $60 \% .{ }^{147}$ But few decisions upholding patents have been appealed to date. And many of them may never be appealed due

144. See U.S. Patent \& Trademark Office, July 2015 Update: Subject Matter ELIGIBILITY 3 (2015), https://www.uspto.gov/sites/default/files/documents/ieg-july-2015update.pdf [https://perma.cc/85LZ-TGEH] ("This discussion is meant to guide examiners and ensure that a claimed concept is not identified as an abstract idea unless it is similar to at least one concept that the courts have identified as an abstract idea.").

145. See Rachel E. Sachs, Innovation Law and Policy: Preserving the Future of Personalized Medicine, 49 U.C. DAVIS L. REV. 1881, 1911 (2016) (describing how the Supreme Court's "adherence to standards over rules in many $\S 101$ cases [has] fostered confusion among the lower courts and within the Federal Circuit" and arguing that "uncertainty ... affects incentives to innovate, as scientists and investors may be reluctant to move forward with product development if they cannot determine whether they will be able to protect their investment"); see also Bernard Chao, The Infringement Continuum, 35 CARDOZO L. REV. 1359, 1386 (2014) ("Many patents in the biotechnology, medical diagnostics, and software industries have an unpatentable concept at their core. But after Mayo, it is unclear whether these patents have added 'enough' to the claims to render them patent eligible.").

146. Descriptively, one might conceptualize this disconnect between the results in precedential opinions and the results in eligibility disputes overall as a variety of "selective transmission"with the court hiding parts of the law from public view in order to achieve broader normative goals. See Meir Dan-Cohen, Decision Rules and Conduct Rules: On Acoustic Separation in Criminal Law, 97 HARV. L. REV. 625, 635, 667 (1984) (defending the use of selective transmission against arguments that it is inconsistent with the rule of law).

147. See Lefstin et al., supra note 108, at 22. 
to settlements or strategic choices by the parties about what arguments to pursue as a case moves forward. ${ }^{148}$

Understanding how the Federal Circuit is using Rule 36 in patentable subject matter cases is important. Litigants and policymakers need to understand that while the law, as it is articulated in precedential appellate opinions, may be setting out guideposts for what is and isn't patentable subject matter, the overwhelming majority of patents challenged under $\S 101$ are failing the test. In other words, the Federal Circuit's post-Alice precedential opinions set out a "framework" of patentable subject matter doctrine, with a handful of decisions defining the overarching structure of the law. While that framework has the benefit of providing a small number of clearly identified doctrinal points of reference, it lacks the information that becomes evident when one looks, as we have in this Article, at the entire population of patentable subject matter decisions. On the whole, those decisions reach different results than the precedential opinions alone. But the entire population of decisions-what the Federal Circuit does "in fact"149_is what, in our view, defines the real contours of patentable subject matter doctrine.

We think, therefore, that more transparency as to the nature of the issues decided would be appropriate, allowing those with an interest in patent law to understand what the law actually is in practice, not

148. Indeed, the arguments about lack of inventiveness or overbreadth that usually form the basis for a $\S 101$ motion often become subsumed within arguments about anticipation, obviousness, or adequate disclosure, in part because most courts treat patentable subject matter as a question of law that is definitively resolved by the judge, usually before trial. See, e.g., ContentGuard Holdings, Inc. v. Apple Inc., No. 2:13-CV-1112, 2016 WL 1637280, at *6 (E.D. Tex. Apr. 25, 2016) (denying Apple's post-trial motion for JMOL of ineligibility, noting that the issue of eligibility was not submitted to the jury and speculating that "[p]erhaps [Apple's] motion is actually a motion for reconsideration" of the court's denial of Apple's request for judgment on the pleadings). Thus, an accused infringer who loses a $§ 101$ motion will understandably move on to emphasize other grounds of invalidity that will be given to the jury-even though, it should be noted, many of those grounds present questions of law, too. See Mark A. Lemley, Why Do Juries Decide If Patents Are Valid?, 99 VA. L. REV. 1673, 1727 (2013) (noting that the Federal Circuit has endorsed the practice of sending the ultimate question of validity to the jury but questioning that approach to resolving questions of law); see also Paul R. Gugliuzza, The Procedure of Patent Eligibility, 97 TEX. L. REV. (forthcoming) (on file with authors) (questioning whether patentable subject matter presents solely a question of law). As this Article was going to press, the Federal Circuit issued two decisions that, unlike many of the court's other post-Alice decisions, emphasized that questions of fact can sometimes underpin the $\$ 101$ analysis. See Aatrix Software, Inc. v. Green Shades Software, Inc., 882 F.3d 1121, 1125 (Fed. Cir. 2018) (holding that factual allegations in the plaintiff's complaint about the patent's inventiveness defeated a motion to dismiss on $\S 101$ grounds); Berkheimer v. HP Inc., 881 F.3d 1360, 1368 (Fed. Cir. 2018) (holding that the question of whether claim elements are "conventional" for $\S 101$ purposes is a question of fact).

149. Oliver Wendell Holmes, Jr., The Path of the Law, 10 HARV. L. REv. 457, 461 (1897), reprinted in 110 HARV. L. REV. 991, 994 (1997). 
just what the precedential opinions say. ${ }^{150}$ To be clear, we're not arguing that the Federal Circuit should write a precedential opinion in every patentable subject matter case. But many lawyers don't have the time (or the financial resources) to dig through dockets and briefs-as we have done to prepare this Article-to determine the basis for the nearly 200 Rule 36 affirmances the Federal Circuit issues every year. A short, nonprecedential opinion making clear the arguments raised by the appellant (and rejected by the court) would provide valuable information. To address any concern that an increase in nonprecedential opinions would distract the court from its work in more important or difficult cases or that the court would be overwhelmed by lawyers citing and relying on nonprecedential opinions in their briefs, ${ }^{151}$ the opinions need not (and probably should not) contain elaborate reasoning. But simply indicating the legal issues considered and rejected would help reduce any misconceptions about how patent appeals are actually resolved. Alternatively, the court itself (or perhaps the Office of the Chief Economist at the PTO) could collect and regularly publish data about the issues raised in cases disposed of via Rule 36. ${ }^{152}$ At minimum, we hope this Article calls attention to the need for scholars, the media, lawyers, and anyone else interested in the patent system to keep a close eye on how "silent" affirmances under Rule 36 may be altering substantive law.

\section{CONCLUSION}

Our study sheds light on the important question of how the law on the books differs from the actual experience of litigants. Some of our findings confirm the conventional wisdom among patent lawyers and

150. Cf. William M. Richman \& William L. Reynolds, Elitism, Expediency, and the New Certiorari: Requiem for the Learned Hand Tradition, 81 CoRnELL L. REV. 273, 285 (1996) (criticizing "no opinion" affirmances, such as those issued under Federal Circuit Rule 36, on the ground that "[e]xplanation" of the basis for a decision "is fundamental to our system of justice").

151. The judges of the Federal Circuit raised similar concerns when opposing the 2006 adoption of Federal Rule of Appellate Procedure 32.1, which overturned prior circuit court rules prohibiting the citation of nonprecedential opinions. See, e.g., Letter from Haldane Robert Mayer, Chief Judge, U.S. Court of Appeals for the Fed. Circuit, to Peter G. McCable, Sec'y, Comm. on Rules of Practice \& Procedure, Admin. Office of the U.S. Courts (Jan. 6, 2004), http://www.uscourts.gov/sites/default/files/fr_import/03-AP-086.pdf [https://perma.cc/6DEYA323].

152. Until 2011, the Federal Circuit Clerk's Office published more detailed data about the court's caseload than is currently available on the court's website. See Jason Rantanen, Federal Circuit Statistics-FY 2011, PATENTLYO (Oct. 26, 2011), https://patentlyo.com/patent/2011/10/ federal-circuit-statistics-fy-2011.html [https://perma.cc/LH4C-QSVJ] (reporting the updated data and removal of previous data). Observers have expressed disappointment about this change in practice. See Paul R. Gugliuzza, Rethinking Federal Circuit Jurisdiction, 100 GEO. L.J. 1437, 1488 n.278 (2012); Rantanen, supra. 
scholars. For example, patentees lose a lot of patentable subject matter disputes, particularly at the Federal Circuit. But someone who's familiar mainly with the court's precedential opinions might be surprised by the magnitude of patentees' loss rate, which exceeds $90 \%$. We also highlighted some intriguing differences in how the court decides to dispose of a case-whether through a precedential opinion, nonprecedential opinion, or Rule 36 affirmance-depending on the result the court reaches. It will be interesting to see if those patterns change as the Federal Circuit reviews more decisions upholding patent validity against $\S 101$ challenges and as patent drafters adjust their behavior to account for the new law of patentable subject matter. 


\section{APPENDIX A}

\section{Federal Circuit Decisions on Patentable Subject Matter June 20, 2014 through June 19, $2017^{153}$}

\section{Precedential Opinions}

Affinity Labs of Tex., LLC v. Amazon.com Inc., 838 F.3d 1266 (Fed. Cir. 2016)

Affinity Labs of Tex., LLC v. DIRECTV, LLC, 838 F.3d 1253 (Fed. Cir. 2016)

Amdocs (Isr.) Ltd. v. Openet Telecom, Inc., 841 F.3d 1288 (Fed. Cir. 2016)

Apple, Inc. v. Ameranth, Inc., 842 F.3d 1229 (Fed. Cir. 2016)

Ariosa Diagnostics, Inc. v. Sequenom, Inc., 788 F.3d 1371 (Fed. Cir. 2015)

Bascom Glob. Internet Servs., Inc. v. AT\&T Mobility LLC, 827 F.3d 1341 (Fed. Cir. 2016)

In re BRCA1- \& BRCA2-Based Hereditary Cancer Test Patent Litig., 774 F.3d 755 (Fed. Cir. 2014)

buySAFE, Inc. v. Google, Inc., 765 F.3d 1350 (Fed. Cir. 2014)

Cleveland Clinic Found. v. True Health Diagnostics LLC, 859 F.3d 1352 (Fed. Cir. 2017)

Content Extraction \& Transmission LLC v. Wells Fargo Bank, 776 F.3d 1343 (Fed. Cir. 2014)

Credit Acceptance Corp. v. Westlake Servs., 859 F.3d 1044 (Fed. Cir. 2017)

DDR Holdings, LLC v. Hotels.com, L.P., 773 F.3d 1245 (Fed. Cir. 2014)

Digitech Image Techs., LLC v. Elecs. for Imaging, Inc., 758 F.3d 1344 (Fed. Cir. 2014)

Elec. Power Grp., LLC v. Alstom S.A., 830 F.3d 1350 (Fed. Cir. 2016)

153. An updated list of the Federal Circuit's post-Alice decisions on patentable subject matter can be found 
Enfish, LLC v. Microsoft Corp., 822 F.3d 1327 (Fed. Cir. 2016)

FairWarning IP, LLC v. Iatric Sys., Inc., 839 F.3d 1089 (Fed. Cir. 2016)

Genetic Techs. Ltd. v. Merial, LLC, 818 F.3d 1369 (Fed. Cir. 2016) Intellectual Ventures I LLC v. Capital One Bank, 792 F.3d 1363 (Fed. Cir. 2015)

Intellectual Ventures I LLC v. Capital One Fin. Corp., 850 F.3d 1332 (Fed. Cir. 2017)

Intellectual Ventures I LLC v. Erie Indem. Co., 850 F.3d 1315 (Fed. Cir. 2017)

Intellectual Ventures I LLC v. Symantec Corp., 838 F.3d 1307 (Fed. Cir. 2016)

Internet Patents Corp. v. Active Network, Inc., 790 F.3d 1343 (Fed. Cir. 2015)

McRO, Inc. v. Bandai Namco Games Am. Inc., 837 F.3d 1299 (Fed. Cir. 2016)

Mortg. Grader, Inc. v. First Choice Loan Servs. Inc., 811 F.3d 1314 (Fed. Cir. 2016)

OIP Techs., Inc. v. Amazon.com, Inc., 788 F.3d 1359 (Fed. Cir. 2015)

Rapid Litig. Mgmt. Ltd. v. CellzDirect, Inc., 827 F.3d 1042 (Fed. Cir. 2016)

RecogniCorp, LLC v. Nintendo Co., 855 F.3d 1322 (Fed. Cir. 2017)

In re Smith, 815 F.3d 816 (Fed. Cir. 2016)

Synopsys, Inc. v. Mentor Graphics Corp., 839 F.3d 1138 (Fed. Cir. 2016)

Thales Visionix Inc. v. United States, 850 F.3d 1343 (Fed. Cir. 2017)

In re TLI Commc'ns LLC Patent Litig., 823 F.3d 607 (Fed. Cir. 2016)

Ultramercial, Inc. v. Hulu, LLC, 772 F.3d 709 (Fed. Cir. 2014)

Versata Dev. Grp., Inc. v. SAP Am., Inc., 793 F.3d 1306 (Fed. Cir. 2015) 


\section{Nonprecedential Opinions}

Allvoice Devs. US, LLC v. Microsoft Corp., 612 F. App’x 1009 (Fed. Cir. 2015)

In re Brown, 645 F. App’x 1014 (Fed. Cir. 2016)

In re Chorna, 656 F. App'x 1016 (Fed. Cir. 2016)

Clarilogic, Inc. v. FormFree Holdings Corp., 681 F. App’x 950 (Fed. Cir. 2017)

Coffelt v. NVIDIA Corp., 680 F. App’x 1010 (Fed. Cir. 2017)

EasyWeb Innovations, LLC v. Twitter, Inc., 689 F. App’x 969 (Fed. Cir. 2017)

Evolutionary Intelligence LLC v. Sprint Nextel Corp., 677 F. App'x 679 (Fed. Cir. 2017)

LendingTree, LLC v. Zillow, Inc., 656 F. App’x 991 (Fed. Cir. 2016)

Planet Bingo, LLC v. VKGS LLC, 576 F. App'x 1005 (Fed. Cir. 2014)

In re Salwan, 681 F. App’x 938 (Fed. Cir. 2017)

Shortridge v. Found. Constr. Payroll Serv., LLC, 655 F. App’x 848 (Fed. Cir. 2016)

Smartflash LLC v. Apple Inc., 680 F. App’x 977 (Fed. Cir. 2017)

TDE Petroleum Data Sols., Inc., v. AKM Enter., Inc., 657 F. App’x 991 (Fed. Cir. 2016)

Trading Techs. Int'l, Inc. v. CQG, Inc., 675 F. App'x 1001 (Fed. Cir. 2017)

Tranxition, Inc. v. Lenovo Inc., 664 F. App’x 968 (Fed. Cir. 2016)

Vehicle Intelligence \& Safety LLC v. Mercedes-Benz USA, LLC, 635 F. App’x 914 (Fed. Cir. 2015)

W. View Research, LLC v. Audi AG, 685 F. App'x 923 (Fed. Cir. 2017)

\section{Rule 36 Affirmances}

In re Alsabah, 677 F. App'x 684 (Fed. Cir. 2017)

Appistry, LLC v. Amazon.com, Inc., 676 F. App’x 1007 (Fed. Cir. 2017) 
Appistry, LLC v. Amazon.com, Inc., 676 F. App’x 1008 (Fed. Cir. 2017)

Athenahealth, Inc. v. CareCloud Corp., 678 F. App’x 1025 (Fed. Cir. 2017)

Becton, Dickinson \& Co. v. Baxter Int'l Inc., 639 F. App’x 652 (Fed. Cir. 2016)

Blue Spike, LLC v. Google Inc., 669 F. App’x 575 (Fed. Cir. 2016)

Broadband iTV, Inc. v. Hawaiian Telcom, Inc., 669 F. App’x 555 (Fed. Cir. 2016)

CallWave Commc'ns LLC v. AT\&T Mobility LLC, 672 F. App’x 995 (Fed. Cir. 2017)

Capital Dynamics v. Cambridge Assocs., LLC, 668 F. App’x 889 (Fed. Cir. 2016)

Chi. Bd. Options Exch., Inc. v. Int'l Sec. Exch., LLC, 640 F. App'x 986 (Fed. Cir. 2016)

Clear with Computs. LLC v. Altec Indus. Inc., 636 F. App'x 1015 (Fed. Cir. 2016)

Cloud Satchel, LLC v. Barnes \& Noble, Inc., 626 F. App'x 1010 (Fed. Cir. 2015)

CMG Fin. Servs., Inc. v. Pac. Tr. Bank, 616 F. App’x 420 (Fed. Cir. 2015)

Concaten, Inc. v. AmeriTrak Fleet Sols., LLC, 669 F. App'x 571 (Fed. Cir. 2016)

Datatreasury Corp. v. Fid. Nat'l Info. Servs., Inc., 669 F. App'x 572 (Fed. Cir. 2016)

DietGoal Innovations LLC v. Bravo Media LLC, 599 F. App’x 956 (Fed. Cir. 2015)

E. Coast Sheet Metal Fabricating Corp. v. Autodesk, Inc., 645 F. App'x 992 (Fed. Cir. 2016)

Essociate, Inc. v. Clickbooth.com, LLC, 641 F. App'x 1006 (Fed. Cir. 2016)

Exergen Corp. v. Sanomedics Int'l Holdings, Inc., 653 F. App'x 760 (Fed. Cir. 2016)

Gametek LLC v. Zynga Inc., 597 F. App’x 644 (Fed. Cir. 2015) 
GoDaddy.com, LLC v. RPost Commc'ns Ltd., 685 F. App’x 992 (Fed. Cir. 2017)

GT Nexus, Inc. v. INTTRA, Inc., 669 F. App’x 562 (Fed. Cir. 2016)

HealthTrio LLC v. Aetna, Inc., 673 F. App’x 1006 (Fed. Cir. 2017)

Integrated Claims Sys., LLC v. Travelers Lloyds of Tex. Ins. Co., 684 F. App'x 959 (Fed. Cir. 2017)

Inventor Holdings, LLC v. Bed Bath \& Beyond, Inc., 643 F. App'x 1014 (Fed. Cir. 2016)

IPLearn-Focus, LLC v. Microsoft Corp., 667 F. App’x 773 (Fed. Cir. 2016)

Jericho Sys. Corp. v. Axiomatics Inc., 642 F. App’x 979 (Fed. Cir. 2016)

Joao Bock Transaction Sys., LLC v. Jack Henry \& Assocs., Inc., 803 F.3d 667 (Fed. Cir. 2015)

Kickstarter, Inc. v. Fan Funded, LLC, 654 F. App'x 481 (Fed. Cir. 2016)

Kombea Corp. v. Noguar L.C., 656 F. App’x 1022 (Fed. Cir. 2016)

Kroy IP Holdings, LLC v. Safeway, Inc., 639 F. App’x 637 (Fed. Cir. 2016)

Linkgine, Inc. v. VigLink, Inc., 689 F. App’x 965 (Fed. Cir. 2017)

Macropoint, LLC v. Fourkites, Inc., 671 F. App'x 780 (Fed. Cir. 2016)

Morales v. Square, Inc., 621 F. App’x 660 (Fed. Cir. 2015)

Morsa v. Facebook, Inc., 622 F. App’x 915 (Fed. Cir. 2015)

Netflix, Inc. v. Rovi Corp., 670 F. App’x 704 (Fed. Cir. 2016)

Network Apparel Grp., LP v. Airwave Networks Inc., 680 F. App’x 1003 (Fed. Cir. 2017)

Nextpoint, Inc. v. Hewlett-Packard Co., 680 F. App’x 1009 (Fed. Cir. 2017)

NexusCard, Inc. v. Kroger Co., 688 F. App’x 916 (Fed. Cir. 2017)

Novo Transforma Techs. LLC v. Sprint Spectrum, L.P., 669 F. App'x 555 (Fed. Cir. 2016)

Open Parking, LLC v. ParkMe, Inc., 683 F. App’x 932 (Fed. Cir. 2017) 
Papst Licensing GmbH \& Co. v. Xilinx, Inc., 684 F. App’x 971 (Fed. Cir. 2017)

Parus Holdings Inc. v. Sallie Mae Bank, 677 F. App’x 682 (Fed. Cir. 2017)

Personalized Media Commc'ns, LLC. v. Amazon.com Inc., 671 F. App’x 777 (Fed. Cir. 2016)

Pres. Wellness Techs. LLC v. Allscripts Healthcare Sols. Inc., 684 F. App’x 970 (Fed. Cir. 2017)

Priceplay.com, Inc. v. AOL Advert., Inc., 627 F. App’x 925 (Fed. Cir. 2016)

RaceTech, LLC v. Ky. Downs, LLC, 676 F. App’x 1009 (Fed. Cir. 2017)

Ret. Capital Access Mgmt. Co. v. U.S. Bancorp, 611 F. App’x 1007 (Fed. Cir. 2015)

SkillSurvey, Inc. v. Checkster LLC, 683 F. App'x 930 (Fed. Cir. 2017)

Voxathon LLC v. FCA US LLC, 671 F. App'x 793 (Fed. Cir. 2016)

In re Webb, 609 F. App’x 643 (Fed. Cir. 2015)

White Knuckle Gaming, LLC v. Elec. Arts, Inc., 683 F. App’x 931 (Fed. Cir. 2017)

Williamson v. Citrix Sys., Inc., 683 F. App’x 956 (Fed. Cir. 2017)

Wireless Media Innovations, LLC v. Maher Terminals, LLC, 636 F. App'x 1014 (Fed. Cir. 2016) 


\section{APPENDIX B}

\section{Regression Analysis Including All Active Judges}

\begin{tabular}{|c|c|c|c|c|c|}
\hline \multicolumn{2}{|c|}{ Regression Stotistics } & & & & \\
\hline Multiple R & 0.4896 & & & & \\
\hline R Square & 0.2397 & & & & \\
\hline Adjusted R Square & 0.1637 & & & & \\
\hline Standard Error & 0.0962 & & & & \\
\hline Observations & 12 & & & & \\
\hline & $d f$ & SS & MS & $F$ & Significance $F$ \\
\hline Regression & 1 & 0.029198942 & 0.02919894 & 3.15249051 & 0.106195915 \\
\hline Residual & 10 & 0.092621824 & 0.00926218 & & \\
\hline Total & 11 & 0.121820766 & & & \\
\hline
\end{tabular}

\begin{tabular}{lcrrrrr}
\hline & Coefficients & Standard Error & \multicolumn{1}{c}{ Stat } & \multicolumn{1}{c}{ P-value } & \multicolumn{1}{c}{ Lower 95\% } & \multicolumn{1}{c}{ Upper 95\% } \\
\hline Intercept & $\mathbf{0 . 4 9 9 4 4 3 6}$ & 0.0484852 & 10.30 & 0.000 & 0.3914118 & 0.6074755 \\
Valid/Total & 0.8611362 & 0.4850036 & 1.78 & 0.106 & -0.2195191 & 1.9417916 \\
\hline
\end{tabular}




\section{APPENDIX C}

Votes Cast in Federal Circuit $§ 101$ Cases by Judges Who Were Not Active Federal Circuit Judges as of June 19, 2017

\begin{tabular}{|l|r|r|r|r|r|r|}
\hline Judge & Valid & \multicolumn{1}{|c|}{ Invalid } & Rule 36 & \multicolumn{2}{|c|}{ Valid/Total } & Rule 36/Invalid \\
\hline Bryson (Senior) & 0 & 11 & 6 & $0.0 \%$ & $54.5 \%$ \\
\hline Mayer (Senior) & 0 & 10 & 4 & $0.0 \%$ & $40.0 \%$ \\
\hline Clevenger (Senior) & 0 & 7 & 5 & $0.0 \%$ & $71.4 \%$ \\
\hline Schall (Senior) & 0 & 7 & 5 & $0.0 \%$ & $71.4 \%$ \\
\hline Linn (Senior) & 0 & 4 & 2 & $0.0 \%$ & $50.0 \%$ \\
\hline Plager (Senior) & 1 & 3 & 1 & $25.0 \%$ & $33.3 \%$ \\
\hline Fogel (N.D. Cal.) & 0 & 1 & 1 & $0.0 \%$ & $100.0 \%$ \\
\hline Stark (D. Del.) & 0 & 1 & 0 & $0.0 \%$ & $0.0 \%$ \\
\hline
\end{tabular}




\section{APPENDIX D}

\section{Regression Analysis Including All Active Judges Plus Judges Bryson and Mayer}

\begin{tabular}{|c|c|c|c|c|c|}
\hline \multicolumn{2}{|c|}{ Regression Statistics } & & & & \\
\hline Multiple R & 0.5470 & & & & \\
\hline R Square & 0.2992 & & & & \\
\hline Adjusted R Square & 0.2408 & & & & \\
\hline Standard Error & 0.0932 & & & & \\
\hline \multirow[t]{2}{*}{ Observations } & 14 & & & & \\
\hline & $d f$ & SS & MS & $F$ & Significance $F$ \\
\hline Regression & 1 & 0.044471387 & 0.04447139 & 5.12406075 & 0.042928112 \\
\hline Residual & 12 & 0.104147213 & 0.00867893 & & \\
\hline Total & 13 & 0.1486186 & & & \\
\hline
\end{tabular}

\begin{tabular}{lrrrrrr}
\hline & Coefficients & Standard Error & \multicolumn{1}{c}{ Stat } & \multicolumn{1}{c}{ P-value } & Lower 95\% & Upper 95\% \\
\hline Intercept & $\mathbf{0 . 4 9 0 4 4 8 2}$ & $\mathbf{0 . 0 3 8 2 2 4 4}$ & 12.83 & $\mathbf{0 . 0 0 0}$ & $\mathbf{0 . 4 0 7 1 6 4 4}$ & $\mathbf{0 . 5 7 3 7 3 2 0}$ \\
Valid/Total & 0.9348816 & 0.4129995 & 2.26 & 0.043 & $\mathbf{0 . 0 3 5 0 3 3 1}$ & 1.8347301 \\
\hline
\end{tabular}


APPENDIX E

Regression Analysis Including All Active Judges Except Judge Newman and Chief Judge Prost

\begin{tabular}{|c|c|c|c|c|c|}
\hline \multicolumn{2}{|c|}{ Regression Stotistics } & & & & \\
\hline Multiple R & 0.1644 & & & & \\
\hline R Square & 0.0270 & & & & \\
\hline Adjusted R Square & -0.0946 & & & & \\
\hline Standard Error & 0.0808 & & & & \\
\hline \multirow[t]{2}{*}{ Observations } & 10 & & & & \\
\hline & $d f$ & SS & MS & $F$ & Significance $F$ \\
\hline Regression & 1 & 0.001451491 & 0.001451491 & 0.2223564 & 0.649842891 \\
\hline Residual & 8 & 0.052222166 & 0.006527771 & & \\
\hline Total & 9 & 0.053673657 & & & \\
\hline
\end{tabular}

\begin{tabular}{lcrrrrr}
\hline & Coefficients & Standard Error & \multicolumn{1}{c}{$t$ Stat } & P-value & \multicolumn{1}{c}{ Lower 95\% } & Upper 95\% \\
\hline Intercept & 0.5525424 & 0.0465664 & 11.87 & 0.000 & 0.4451602 & 0.6599247 \\
Valid/Total & 0.2488529 & 0.5277374 & 0.47 & 0.650 & -0.9681117 & 1.4658174 \\
\hline
\end{tabular}

